\title{
Morphological characterization and taxonomic key of tadpoles (Amphibia: Anura) from the northern region of the Atlantic Forest
}

\author{
Marcos Jorge Matias Dubeux ${ }^{1,2,3} \mathbb{1}^{(0)}$, Filipe Augusto Cavalcanti do Nascimento ${ }^{2,3(\mathbb{0})}$, \\ Luana Rodrigues Lima ${ }^{2,3}$, Felipe de Medeiros Magalhães ${ }^{4,5}$, Izabel Regina Soares da Silva ${ }^{4,6}$, Ubiratan \\ Gonçalves $^{2,3}$, João Paulo Felix Almeida ${ }^{2,3}$, Larissa Lima Correia ${ }^{2,3}$, Adrian Antonio Garda ${ }^{4,5}$, \\ Daniel Oliveira Mesquita ${ }^{\left.4,6^{(}\right)}$, Denise de Cerqueira Rossa-Feres ${ }^{{ }^{(\mathbb{D})}}$ \& Tamí Mott $^{2,3}$ \\ ${ }^{1}$ Universidade Federal de Pernambuco, Departamento de Zoologia, Laboratório de Herpetologia, Programa de \\ Pós-Graduação em Biologia Animal, Recife, PE, Brasil. \\ ${ }^{2}$ Universidade Federal de Alagoas, Instituto de Ciências Biológicas e da Saúde, Laboratório de Biologia \\ Integrativa, Maceió, AL, Brasil. \\ ${ }^{3}$ Universidade Federal de Alagoas, Museu de História Natural, Setor de Herpetologia, Maceió, AL, Brasil. \\ ${ }^{4}$ Universidade Federal da Paraíba, Departamento de Sistemática e Evolução, Programa de Pós-graduação em \\ Ciências Biológicas (Zoologia), João Pessoa, PB, Brasil. \\ ${ }^{5}$ Universidade Federal do Rio Grande do Norte, Departamento de Botânica e Zoologia, Laboratório de Anfibios e \\ Répteis, Natal, RN, Brasil. \\ ${ }^{6}$ Universidade Federal da Paraíba, Departamento de Sistemática e Evolução, Laboratório de Herpetologia, João \\ Pessoa, PB, Brasil. \\ ${ }^{7}$ Universidade Estadual Paulista - UNESP, Departamento de Zoologia e Botânica, Laboratório de Ecologia Teórica, \\ São José do Rio Preto, SP, Brasil. \\ *Corresponding author: Marcos Jorge Matias Dubeux, e-mail:marcosdubeux.bio@gmail.com
}

DUBEUX, M.J.M., NASCIMENTO, F.A.C. do., LIMA, L.R., MAGALHÃES, F. de M., SILVA, I.R.S da, GONÇALVES, U., ALMEIDA, J.P.F., CORREIA, L.L., GARDA, A. A., MESQUITA, D.O., ROSSA-FERES, D.C., MOTT, T. Morphological characterization and taxonomic key of tadpoles (Amphibia: Anura) from the northern region of the Atlantic Forest. Biota Neotropica 20(2): e20180718. https://doi.org/10.1590/1676-0611-BN-2018-0718

\begin{abstract}
Although anuran tadpoles are widely distributed and abundant in tropical aquatic habitats, there is a lack of taxonomic keys for the Atlantic Forest. Herein, we developed a dichotomous key for identifying the tadpoles for all species with known larval phase and already recorded in the Atlantic Forest north of the São Francisco River. We analyzed discrete characteristics of 1,042 tadpoles encompassing 63 species of 28 genera from 32 localities. The userfriendly key includes illustration and pictures, and it is a significant step towards improving our knowledge of tadpoles of the Atlantic Forest.

Keywords: larval phase; anuran amphibians; Neotropical region.

\section{Caracterização morfológica e chave taxonômica de girinos (Amphibia: Anura) da região norte da Mata Atlântica}

Resumo: Embora os girinos de anuros sejam amplamente distribuídos e abundantes em habitats aquáticos tropicais, não há chaves taxonômicas suficientes para as espécies da Mata Atlântica. Aqui, desenvolvemos uma chave dicotômica para identificar os girinos de todas as espécies com fase larval conhecida e já registradas nesse bioma, ao norte do rio São Francisco. Nós analisamos características discretas de 1.042 girinos pertencentes a 63 espécies (28 gêneros) de 32 localidades. Esta chave de identificação inclui ilustrações e imagens, sendo um passo significativo para um melhor conhecimento dos girinos da Mata Atlântica.

Palavras-chave: fase larval; anfibios anuros; Região Neotropical. 


\section{Introduction}

The majority of the more than 7,000 currently known species of anurans (AmphibiaWeb 2020, Frost 2020) have a larval phase (Altig $\&$ McDiarmid 1999). Tadpoles occur in a great variety of aquatic habitats, including ponds, streams, phytotelmata, and shallow films of water in splash zones of rivers and waterfalls (Altig \& McDiarmid 1999). Tadpoles experience a variety of selective pressures in aquatic habitats and thus exhibit extensive ecological and morpho-functional variation (Duellman \& Trueb 1994, Altig \& McDiarmid 1999, Rolents et al. 2011, Sherrat et al. 2017, 2018).

Although the number of studies on Neotropical tadpoles is growing, there are still several knowledge gaps regarding their natural history, habitat use, microhabitat occupation, feeding behavior and ecology (Provete et al. 2012, Rossa-Feres et al. 2015). Brazil harbors the richest amphibian fauna worldwide (AmphibiaWeb 2020), yet tadpoles have been described for only about $60 \%$ of its species (Provete et al. 2012). Furthermore, this number is underestimated because many new species have been described without the larval phase being reported (Rossa-Feres et al. 2015). This gap in tadpole descriptions is further compounded by the few identification keys available for Neotropical tadpoles (e.g., Lips \& Savage 1996, Rossa-Feres \& Nomura 2006, Schulze et al. 2015), which are restricted to specific regions. For the Atlantic Forest, home to a remarkable diversity of anurans (more than 625 species) with high endemism (78\%) (Rossa-Feres et al. 2017), identification keys are only available for the Southern and Southeastern regions (Rossa-Feres \& Nomura 2006, Machado \& Maltchink 2007, Pimenta et al. 2014, Fatorelli et al. 2017, Pezzuti et al. 2019). The limited number of taxonomic keys hampers the correct identification of anuran larvae, thus hindering studies on ecology, systematics and conservation (Altig \& McDiarmid 1999, Andrade et al. 2007).

The Atlantic Forest north of the São Francisco River is also known as the Pernambuco biogeographical sub-region (Ribeiro et al. 2009). This sub-region is characterized by dense ombrophilous vegetation, most of it replaced by monocultures and pastures (Assis 2000, Studer et al. 2015), resulting in a vastly fragmented landscape with most fragments smaller than 50 ha and the largest less than 10,000 ha (Ribeiro et al. 2009). Together, these fragments cover about 379,818 ha of the Brazilian states of Alagoas, Pernambuco, Paraíba and Rio Grande do Norte (Ribeiro et al. 2009).

Nonetheless, 77 anuran species (12\% of the known richness of the Atlantic Forest) of 34 genera and 15 families (Aromobatidae, Bufonidae, Centrolenidae, Ceratophryidae, Craugastoridae, Eleutherodactylidae, Hemiphractidae, Hylidae, Hylodidae, Leptodactylidae, Microhylidae, Odontophrynidae, Phyllomedusidae, Pipidae, and Ranidae) occur in this biogeographical region and its transitional areas (for species list and reference see Supplementary Material 1). Seven of these species are endangered (Allobates olfersioides, Adelophryne baturitensis, Chiasmocleis alagoana, Crossodactylus dantei, Hylomantis granulosa, Phyllodytes gyrinaethes, and Physalaemus caete), while 14 species are endemic (ICMBio 2018, Vilela et al. 2018, IUCN 2020).

Herein, we provide a user-friendly dichotomous key for anuran larvae of 63 out of 77 anuran species occurring in the Atlantic Forest north of the São Francisco River, and a morphological characterization for 28 genera and 15 species groups in those genera with great morphological diversity.

\section{Material and Methods}

We analyzed 1,042 tadpoles collected from 32 localities (Figure 1) and encompassing 63 species from 28 genera occurring in the northern region of the Atlantic Forest (north of the São Francisco River). Species of three genera occurring in the region, Pristimantis Jiménez-de-la-Espada, 1870 (Craugastoridae), Adelophryne Hoogmoed \& Lescure, 1984 (Eleutherodactylidae) and Gastrotheca Fitzinger, 1843 (Hemiphractidae), were not included because they exhibit direct development (i.e., they do not go through a larval phase; Hedges et al. 2008, Duellman \& Trueb 2015). Moreover, tadpoles of Vitreorana baliomma Pontes, Caramaschi \& Pombal, 2014 (Centrolenidae), Ceratophrys joazeirensis Mercadal de Barrio, 1986 (Ceratophryidae), Crossodactylus dantei Carcerelli \& Caramaschi, 1993 (Hylodidae), Leptodactylus ochraceus Lutz, 1930 (Leptodactylidae), and those of the hylids Boana exastis (Caramaschi \& Rodrigues, 2003), Ololygon muriciensis Cruz, Nunes \& Lima, 2011, S. cretatus Nunes \& Pombal, 2011 and Sphaenorhynchus cammaeus Roberto, Araujo-Vieira, Carvalho-e-Silva \& Ávila, 2017 were not included because their tadpoles have not been described.

All examined specimens are housed in the following herpetological collections: Coleção de Anfíbios do Museu de História Natural da Universidade Federal da Bahia (UFBA), Coleção de Anfíbios da Universidade Estadual Paulista, São José do Rio Preto (DZSJRP), Coleção Herpetológica do Museu de História Natural da Universidade Federal de Alagoas (MUFAL), Coleção Herpetológica do Museu de Zoologia da Universidade Estadual de Santa Cruz (MZUESC), Coleção Herpetológica do Museu de Zoologia da Universidade Estadual de Feira de Santana (MZFS), Coleção Herpetológica da Universidade Federal da Paraíba (CHUFPB), Coleção Herpetológica da Universidade Federal de Pernambuco (CHUFPE), and Laboratório de Herpetologia da Universidade Federal de Campina Grande (LHUFCG). Specimens were identified up to species level based on one of the following methods: (i) DNA barcoding approach (fragment of mitochondrial $16 \mathrm{~S}$ rRNA) gene, (ii) observation of metamorphosed specimens in captivity, (iii) developing from eggs obtained from identified mating pairs, (iv) larvae from the same lot used in the original description of the species, or (v) direct comparison with the original description. Species nomenclature followed Frost (2020).

Because morphological features vary along tadpole's ontogenetic development (Altig \& McDiarmid 1999, Grosjean 2005, Laufer et al. 2013), we evaluated 21 morphological characteristics in tadpoles at development stages 30-40 (Gosner 1960), and 51-58 (Niewkoop \& Faber 1956) for Pipa larvae. Nevertheless, if these stages were not available, adjacent younger and older tadpoles were examined. Morphological characterization and terminology followed Altig \& McDiarmid (1999): body shape in dorsal and lateral views; snout shape in dorsal and lateral views; eye position, nostrils aperture configuration; distance of nostrils from the tip of the snout and eyes; presence and position of the oral disc, distribution of marginal papillae; labial tooth row formula (LTRF); spiracle number and position; vent tube position; dorsal fin origin; dorsal and ventral fins height and contour; relative length of tail; tail tip shape; and presence of flagellum (only for those who have it). All observations were made using a Coleman ${ }^{\circ}$ NSZ 405 stereomicroscope.

To define body morphogeometric states to standardize nomenclature, at least three taxonomically unrelated species were used. The body 

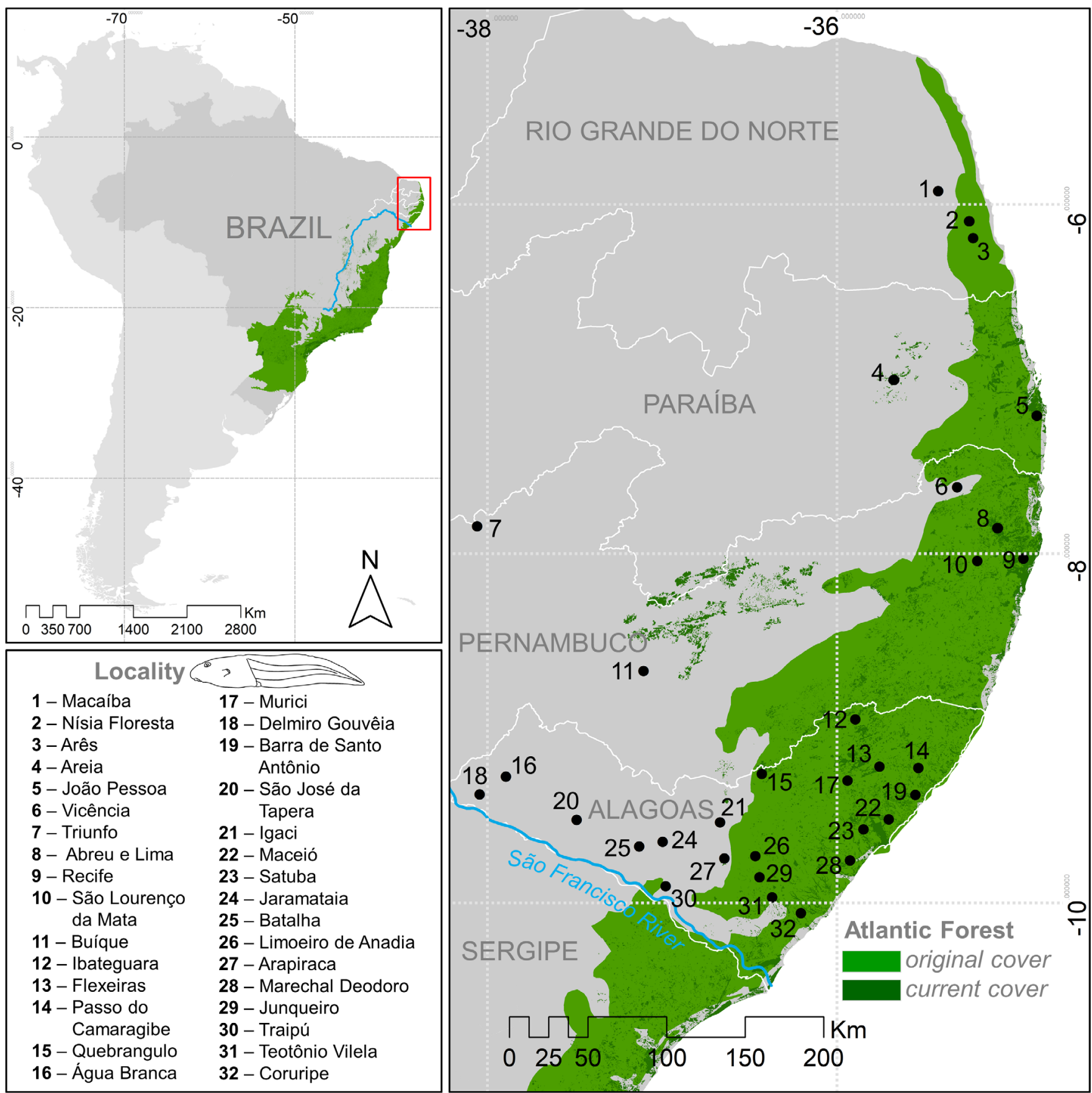

Figure 1. Map of to the study area, northern portion of the Atlantic Forest located north of the São Francisco River. Black circles correspond to the locations from which the analyzed tadpoles came from. Inset map: South America.

contour around those corresponding shapes was blended for a better view of shape variations in one same state seeking to eliminate the effect of rotation and scaling. The resulting shapes are shown in Figure 2.

The identification key was elaborated in a taxonomically inclusive way, with terminals at family, genus, species group (following the most current phylogenetic proposals, see below) and species. Exception to two pairs of species: Phyllodytes brevirostris Peixoto \& Cruz, 1988 and P. edelmoi Peixoto, Caramaschi \& Freire, 2003; and the pairs Physalaemus albifrons (Spix, 1824) and P. cuvieri Fitzinger, 1826 , which were reciprocally grouped together in the same terminal because no morphological variations that diagnosed these tadpoles were identified. Characters grouping monophyletic taxa were preferred over those grouping ecomorphotypes. People with different degrees of knowledge about tadpole morphology tested the key.

The characterization of genera and species groups followed the following sequence: (i) list of the species that occur in the region and the locality from where the described tadpoles were obtained, (ii) list of the examined specimens, with the following data: acronym and catalog number in scientific collections, number of individuals analyzed, range of developmental stages, and locality from where the tadpoles were 

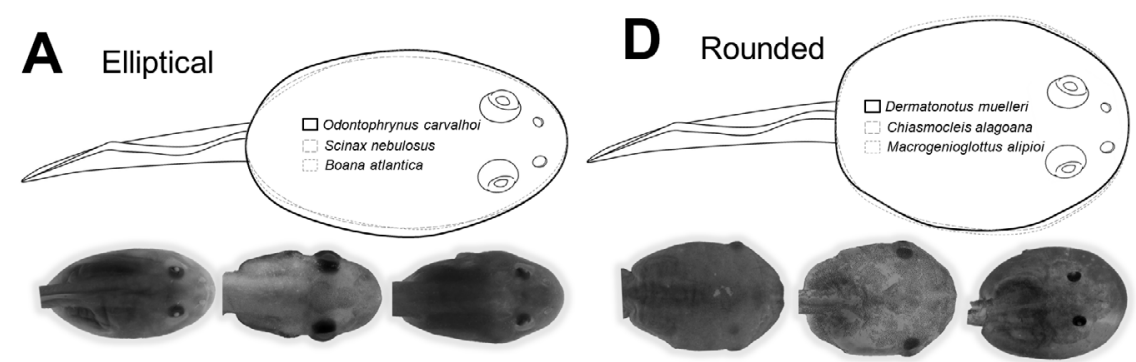

B Elliptical-elongated
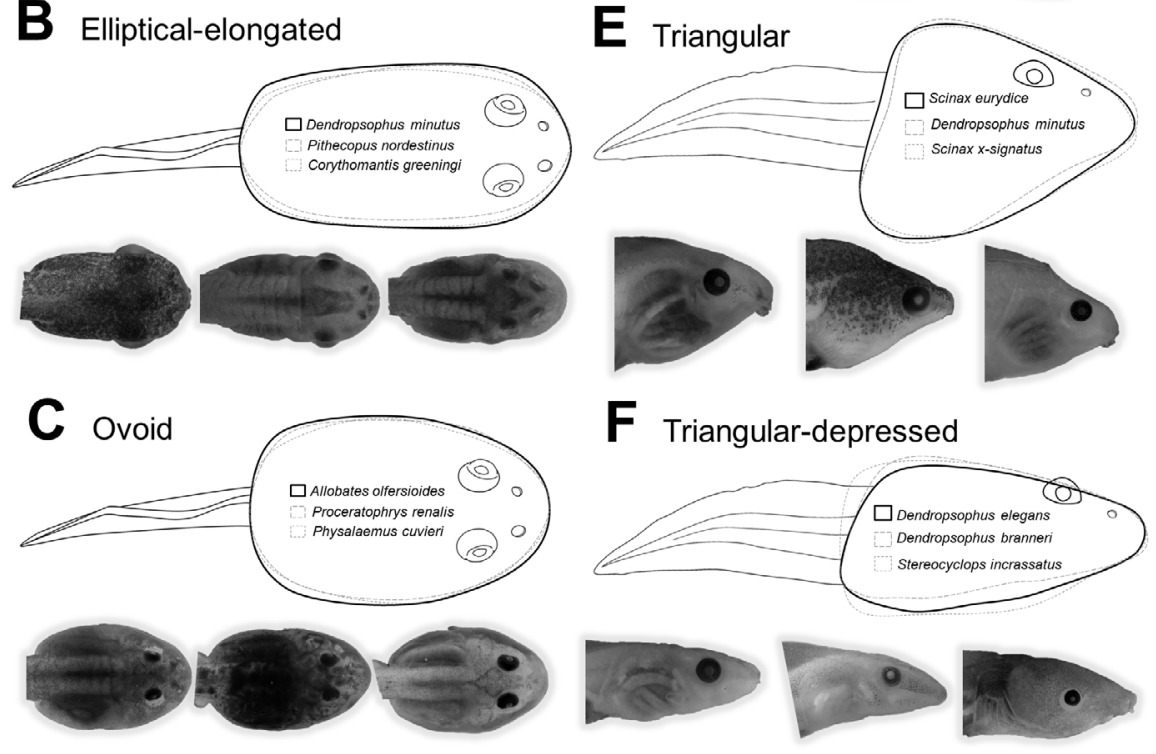
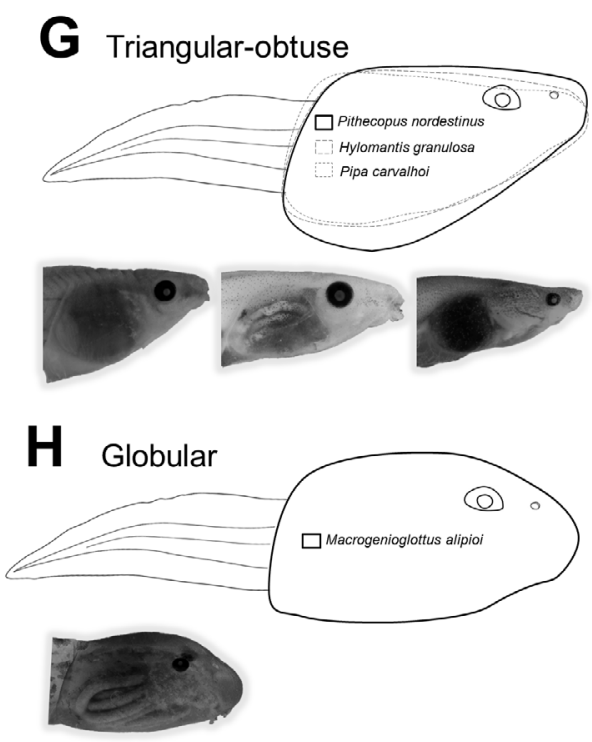

| Globular-depressed

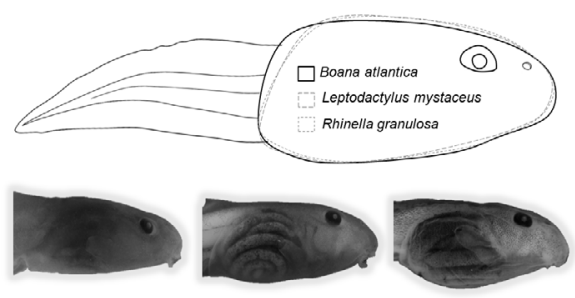

Figure 2. Standardization proposal of morphogeometric characteristics used for larval characterizations and in the taxonomic key.

obtained, (iii) morphological characterization of specimens examined, (iv) notes: comparison with tadpoles described from other localities, if morphological differences were detected.

\section{Results}

\section{Morphological characterization}

\section{Family Aromobatidae}

Allobates Zimmermann \& Zimmermann, 1988

Species occurring in the region. Allobates olfersioides (Lutz, 1925) (Figure 3A): Verdade \& Rodrigues (2007), municipality of Rio de Janeiro, state of Rio de Janeiro, Brazil.

Specimens examined. Allobates olfersioides: MUFAL 11083, 13953 $(\mathrm{n}=9$, stages 28-32), municipality of Maceió; MUFAL $12465(\mathrm{n}=11$, stages 30-36), municipality of Teotônio Vilela; both from the state of Alagoas, Brazil.

Characteristics: Body ovoid in dorsal view, globular-depressed in lateral view. Snout oval in dorsal and lateral views. Nostrils reniform, closer to snout than to eyes. Eyes dorsal. Oral disc anteroventral, emarginate laterally. Marginal papillae arranged lateroventrally, with a wide dorsal gap. LTRF 2(2)/3. Upper jaw sheath with medial reentrance. Spiracle sinistral. Vent tube medial. Dorsal fin originating at tail-body junction, dorsal and ventral fins parallel to longitudinal axis of tail. Tail length about $70 \%$ of total length, tail tip acute.

Notes: The tadpoles of $A$. olfersioides described by Verdade \& Rodrigues (2007) from Tijuca, state of Rio de Janeiro, Brazil, differ from those studied here by having the LTRF 2(1)/3, nostrils circular and dorsal fin originating on the body.

\section{Family Bufonidae}

Frostius Cannatella, 1986

Species occurring in the region. Frostius pernambucensis (Bokermann, 1962) (Figure 3B): Cruz \& Peixoto (1982), municipality of Recife, state of Pernambuco, Brazil.

Specimens examined. Frostius pernambucensis: MUFAL 14572 $(\mathrm{n}=5$, stages 41-42), municipality of Murici, state of Alagoas, Brazil.

Characteristics: Body ovoid in dorsal view, globular-depressed in lateral view. Snout oval in dorsal view, truncate in lateral view. Nostrils reniform, closer to eyes than to tip of snout. Eyes dorsal. Oral disc ventral. Marginal papillae absent. LTRF $1 / 1$ arranged on a thick dermal fold. Spiracle sinistral. Vent tube medial. Dorsal fin originating at tail-body junction, dorsal fin slightly arched and ventral fin parallel to longitudinal axis of tail. Tail length about $70 \%$ of total length, tail tip acute.

Rhinella Fitzinger, 1826

Species occurring in the region. Rhinella crucifer (Wied-Neuwied, 1821) (Figure 3C): Ruas et al. (2012), municipality of Igrapiúna, 


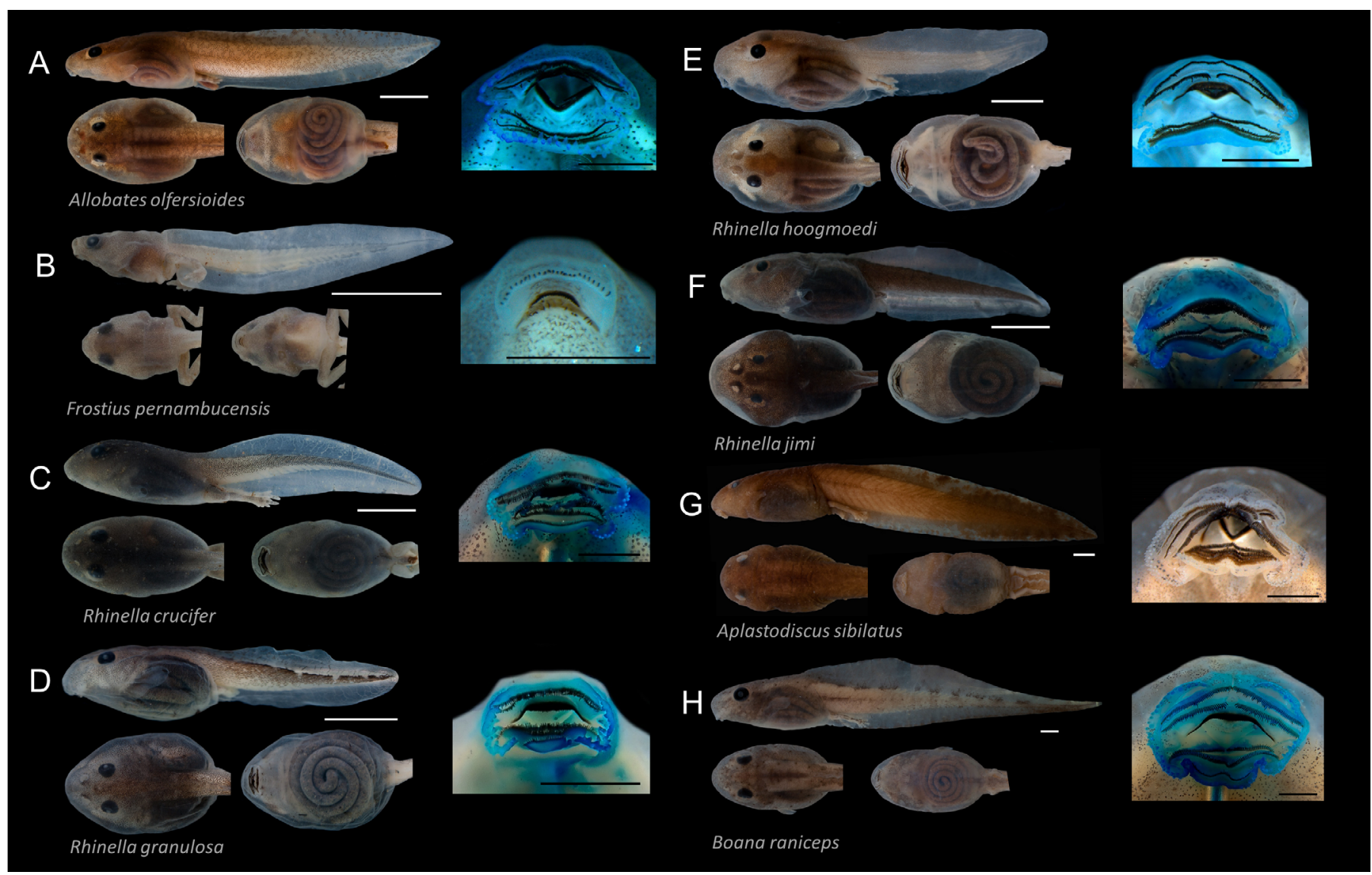

Figure 3. Lateral, dorsal and ventral views $(\mathrm{scale}=3 \mathrm{~mm})$ and oral disc $(\mathrm{scale}=1 \mathrm{~mm})$ of tadpoles occurring in the north of the Atlantic Forest.

state of Bahia, Brazil. Rhinella granulosa (Spix, 1824) (Figure 3D): Lynch (2006), Colombia; Mercês et al. (2009), municipality of Feira de Santana, state of Bahia, Brazil. Rhinella hoogmoedi Caramaschi \& Pombal, 2006 (Figure 3E): Mercês et al. (2009), municipality of Igrapiúna, state of Bahia, Brazil. Rhinella jimi (Stevaux, 2002) (Figure 3F): Mercês et al. (2009), municipality of Feira de Santana, state of Bahia, Brazil; Tolledo \& Toledo (2010), archipelago of Fernando de Noronha, state of Pernambuco, Brazil.

Specimens examined. Rhinella crucifer: MUFAL $15450(\mathrm{n}=10$, stages 35-37), municipality of Quebrangulo, state of Alagoas, Brazil. Rhinella granulosa: MUFAL $13877(\mathrm{n}=7$, stages 33-34), municipality of Arapiraca; MUFAL 13882, 13887 ( $n=10$, stages 38-40), municipality of Batalha; both from the state of Alagoas, Brazil. Rhinella hoogmoedi: MUFAL 12502 ( $\mathrm{n}=15$, stages 30-37), municipality of Murici, state of Alagoas, Brazil. Rhinella jimi: MUFAL 13883 ( $\mathrm{n}=11$, stages 30-37), municipality of Arapiraca; MUFAL $13890(n=5$, stage 30), municipality of Jaramataia; MUFAL 13897 ( $\mathrm{n}=11$, stages 37-40), municipality of Traipú; all from the state of Alagoas, Brazil; CHUFPB 28091 ( $\mathrm{n}=20$, stages 30-40), municipality of Areia, state of Paraíba, Brazil.

Characteristics: Body ovoid or elliptical in dorsal view, globulardepressed in lateral view. Snout oval or rounded in dorsal view, oval in lateral view. Nostrils reniform, closer to eyes than to tip of snout. Eyes dorsal. Oral disc ventral, emarginate laterally. Marginal papillae arranged laterally, with a wide dorsal gap and a wide ventromedial gap.
LTRF 2(2)/3. Spiracle sinistral. Vent tube medial. Dorsal fin originating at tail-body junction, dorsal fin and ventral fin arched. Tail length approximately $60 \%$ of total length, tail tip rounded.

\section{Family Hylidae}

Aplastodiscus Lutz, 1950

Species occurring in the region. Aplastodiscus sibilatus (Cruz, Pimenta \& Silvano, 2003) (Figure 3G): Mercês \& Juncá (2010), municipality of Santa Terezinha, state of Bahia, Brazil.

Specimens examined. Aplastodiscus sibilatus: MUFAL 10847 (n $=9$, stages 30-40), municipality of Murici, state of Alagoas, Brazil.

Characteristics: Body elliptical in dorsal view, globular-depressed in lateral view. Snout oval in dorsal and lateral views. Nostrils elliptical, closer to eyes than to tip of snout. Eyes dorsal. Oral disc ventral, with two emarginations on posterior margin. Marginal papillae arranged lateroventrally, with a short dorsal gap. LTRF 3(1,3)/5(1). Spiracle sinistral. Vent tube dextral. Dorsal fin originating at tail, dorsal and ventral fins parallel to longitudinal axis of tail. Tail length about $70 \%$ of total length, tail tip acute.

\section{Boana Gray, 1825}

Species occurring in the region. Boana albopunctata species group (Faivovich et al. 2005) - Boana raniceps (Cope, 1862) (Figure 3H): Kolenc et al. (2008), Argentina; Schulze et al. (2015), Bolivia. Boana faber species group (Faivovich et al. 2005) - Boana albomarginata (Spix, 1824) (Figure 4A): Peixoto \& Cruz (1983), municipalities of 
Rio de Janeiro (Grumari's administrative region) and Itaguaí; both from the state of Rio de Janeiro, Brazil, and municipality of Recife, state of Pernambuco, Brazil. Boana crepitans (Wied-Neuwied, 1824) (Figure 4B): Kenny (1968), Trinidad; Lynch (2006), Colombia; Casal \& Juncá (2008), municipality of Feira de Santana, state of Bahia, Brazil. Boana faber (Wied-Neuwied, 1821) (Figure 4C): Cei (1980) and Kolenc et al. (2008), Argentina. Boana pulchella species group (Faivovich et al. 2005) - Boana freicanecae (Carnaval \& Peixoto, 2004) (Figure 4D): Carnaval \& Peixoto (2004), municipality of Jaqueira, state of Pernambuco, Brazil. Boana punctata species group (Faivovich et al. 2005) - Boana atlantica (Caramaschi \& Velosa, 1996) (Figure 4E): Nascimento et al. (2009), municipality of Maceió, state of Alagoas, Brazil. Boana semilineata species group (Faivovich et al. 2005) - Boana semilineata (Spix, 1824) (Figure 4F): Bokermann (1963), municipality of Piassaguera, state of São Paulo, Brazil.

Specimens examined. Boana albomarginata: MUFAL $10146(\mathrm{n}=$ 15, stages 30-34), municipality of Maceió, state of Alagoas; CHUFPB 27211 ( $\mathrm{n}=2$, stage 37), municipality of Macaíba, state of Rio Grande do Norte, Brazil. Boana atlantica: MUFAL $4755(n=6$, stages 30-40), municipality of Maceió, state of Alagoas, Brazil. Boana crepitans: MUFAL 15452 ( $\mathrm{n}=5$, stages 27-29), municipality of Quebrangulo, state of Alagoas, Brazil. Boana faber: MUFAL 15453 ( $n=10$, stage 26), municipality of Porto Seguro, state of Bahia, Brazil; this locality is from south of the São Francisco River, but it was considered here because although there are records of this species for the northern
Atlantic Forest (Almeida et al. 2016), there are no tadpole specimens. Boana freicanecae: MUFAL 10779 ( $\mathrm{n}=7$, stages 30-34), municipality of Murici, state of Alagoas, Brazil. Boana raniceps: MUFAL 12497 (n = 9, stages 36-39), municipality of Barra de Santo Antônio, state of Alagoas, Brazil; CHUFPB 28471-72 ( $\mathrm{n}=4$, stages 26-31), municipality of João Pessoa, state of Paraíba, Brazil; CHUFPB 28221 ( $n=2$, stages 31-34), municipality of Macaíba, state of Rio Grande do Norte, Brazil. Boana semilineata: MUFAL $9711(\mathrm{n}=10$, stages 30-32), municipality of Maceió, state of Alagoas, Brazil; CHUFPE-A 1130 ( $\mathrm{n}=1$, stages 38), municipality of Vicência, state of Pernambuco, Brazil.

Characteristics: Boana albopunctata species group - Body ovoid in dorsal view, globular-depressed in lateral view. Snout oval in dorsal view, acuminate in lateral view. Nostrils reniform, equally distant from eyes and tip of snout. Eyes dorsal. Oral disc ventral, with two emarginations on posterior margin. Marginal papillae arranged lateroventrally, with a wide dorsal gap. LTRF 2(1,2)/3(1). Spiracle sinistral. Vent tube dextral. Dorsal fin originating at tail-body junction, dorsal fin arched, ventral fin parallel to longitudinal axis of tail. Tail length approximately $60 \%$ of total length, tail tip acute.

Boana faber species group - Body ovoid in dorsal view, globulardepressed in lateral view. Snout oval in dorsal and lateral views. Nostrils reniform, equally distant from eyes and tip of snout. Eyes dorsal. Oral disc anteroventral, with two emarginations on posterior margin. Marginal papillae arranged lateroventrally, with a short dorsal gap. LTRF 2(1)/4(1) or 2(1)/3(1). Spiracle sinistral. Vent tube dextral.
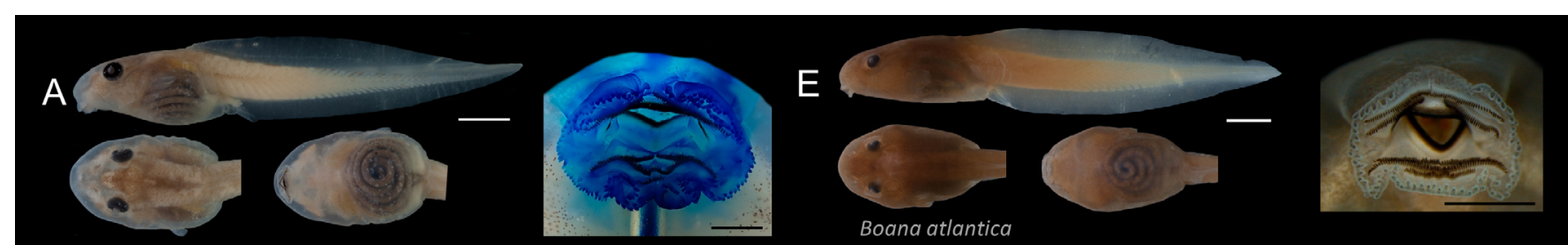

Boana albomarginata
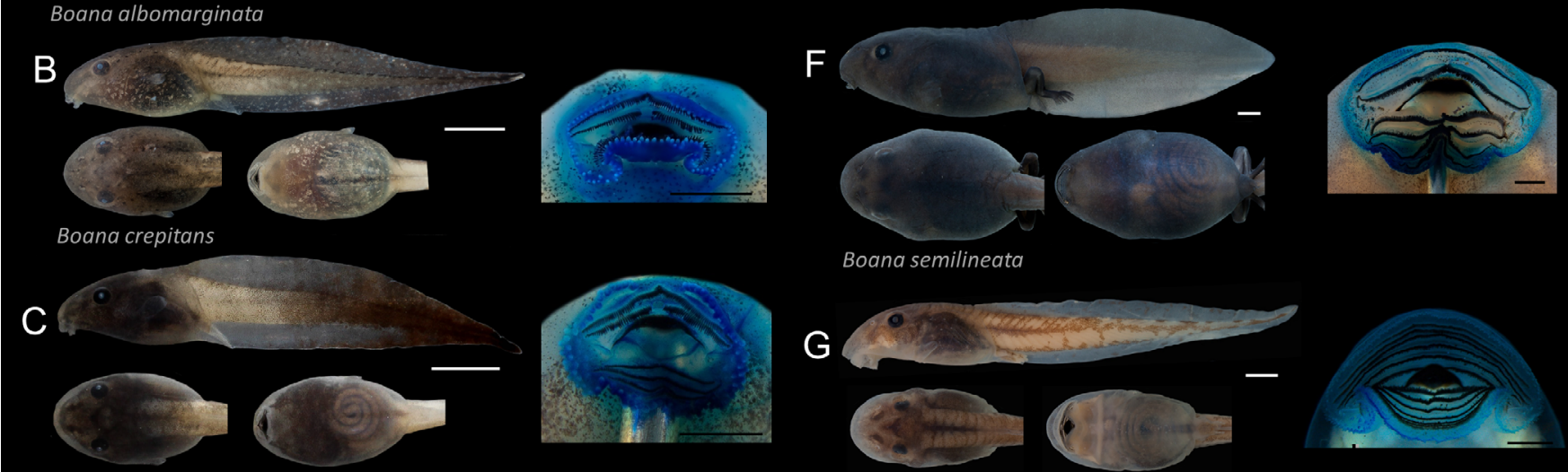

Boana semilineata

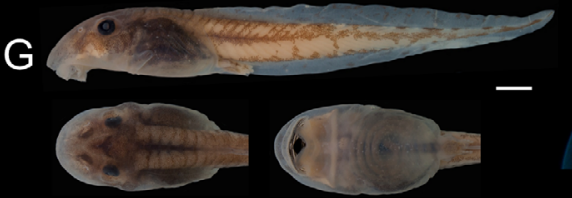

Corythomantis greeningi
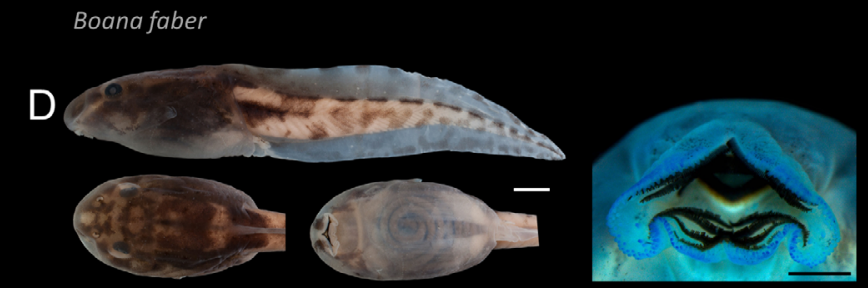

Boana freicanecae

$\mathrm{H}$
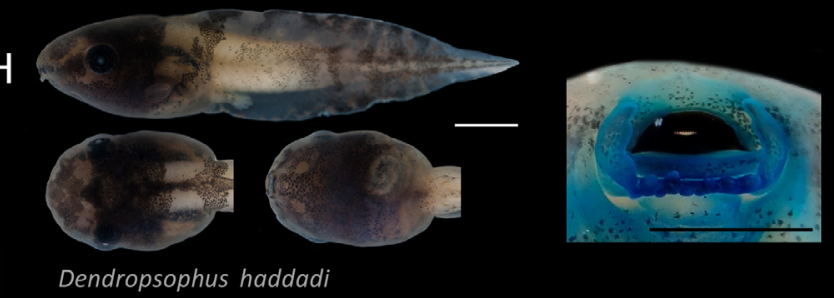

Dendropsophus haddadi

Figure 4. Lateral, dorsal and ventral views (scale $=3 \mathrm{~mm}$ ) and oral disc (scale $=1 \mathrm{~mm}$ ) of tadpoles occurring in the north of the Atlantic Forest. 
Dorsal fin originating at tail-body junction, dorsal and ventral fins parallel to longitudinal axis of tail. Tail length approximately $60 \%$ of total length, tail tip acute.

Boana pulchella species group - Body elliptical in dorsal view, globular-depressed in lateral view. Snout oval in dorsal and lateral views. Nostrils reniform, equally distant from eyes and tip of snout. Eyes dorsal. Oral disc ventral, two emarginations on posterior margin. Marginal papillae arranged lateroventrally, with a wide dorsal gap. LTRF $2(1,2) / 4(1)$. Spiracle sinistral. Vent tube dextral. Dorsal fin originating at tail-body junction. Dorsal and ventral fins parallel to longitudinal axis of tail. Tail length approximately $60 \%$ of total length, tail tip acute.

Boana punctata species group - Body elliptical in dorsal view, globular-depressed in lateral view. Snout rounded in dorsal view, oval in lateral view. Nostrils reniform, equally distant from eyes and tip of snout. Eyes dorsal. Oral disc anteroventral, two emarginations on posterior margin. Marginal papillae arranged lateroventrally, with a wide dorsal gap. LTRF 2(1,2)/3(1). Spiracle sinistral. Vent tube dextral. Dorsal fin originating at tail-body junction, dorsal and ventral fins parallel to longitudinal axis of tail. Tail length approximately $60 \%$ of total length, tail tip acute.

Boana semilineata species group - Body oval in dorsal view, globular-depressed in lateral view. Snout oval in dorsal and lateral views. Nostrils reniform, equally distant from eyes and tip of snout. Eyes dorsal. Oral disc anteroventral, two emarginations on posterior margin. Marginal papillae arranged lateroventrally, with a wide dorsal gap. LTRF 2(2)/4(1). Spiracle sinistral. Vent tube dextral. Dorsal fin originating at tail-body junction, dorsal and ventral fins arched. Tail length approximately $60 \%$ of total length, tail tip acute.

Corythomantis Boulenger, 1896

Species occurring in the region. Corythomantis greeningi Boulenger, 1896 (Figure 4G): Juncá et al. (2008), municipalities of Feira de Santana and Morro do Chapéu; both from the state of Bahia, Brazil.

Specimens examined. Corythomantis greeningi: MUFAL 13688 ( $\mathrm{n}$ $=11$, stages 30-40), municipality of Murici, state of Alagoas, Brazil; CHUFPB 28023 ( $\mathrm{n}=20$, stages 36-38), municipality of Macaíba, state of Rio Grande do Norte, Brazil.

Characteristics: Body elliptical-elongated in dorsal view, globulardepressed in lateral view. Snout rounded in dorsal view, sloped in lateral view. Nostrils rounded, closer to eyes than to tip of snout. Eyes dorsal. Oral disc ventral, two emarginations on posterior margin. Marginal papillae without gaps. LTRF 6(6)/7[8](1). Spiracle sinistral. Vent tube dextral. Dorsal fin originating at tail-body junction, dorsal and ventral fins parallel to longitudinal axis of tail. Tail length about $70 \%$ of total length, tail tip acute.

\section{Dendropsophus Fitzinger, 1843}

Species occurring in the region. Dendropsophus decipiens species group (Faivovich et al. 2005) - Dendropsophus haddadi (Bastos \& Pombal, 1996) (Figure 4H): Abreu et al. (2013), municipality of Mata de São João, state of Bahia, Brazil. Dendropsophus oliveirai (Bokermann, 1963) (Figure 5A): Pugliese et al. (2000), municipality of Quebrangulo, state of Alagoas, Brazil. Dendropsophus leucophyllatus species group (Faivovich et al. 2005) - Dendropsophus elegans (WiedNeuwied, 1824) (Figure 5B): Gomes \& Peixoto (1991a), municipalities of Maricá and Magé; both from the state of Rio de Janeiro, Brazil. Dendropsophus marmoratus species group (Faivovich et al. 2005) Dendropsophus soaresi (Caramaschi \& Jim, 1983) (Figure 5C), Gomes
\& Peixoto (1991b), municipality of Magé, state of Rio de Janeiro and municipality of Linhares, state of Espírito Santo, Brazil. Dendropsophus microcephalus species group (Faivovich et al. 2005) - Dendropsophus branneri (Cochran, 1948) (Figure 5D): Abreu et al. (2015a), municipality of Igarassu, state of Pernambuco, Brazil. Dendropsophus nanus (Boulenger, 1889) (Figure 5E): Lavilla (1990), Argentina; Hero (1990), municipality of Manaus, state of Amazonas, Brazil; Schulze et al. (2015), Bolivia. Dendropsophus studerae (Carvalho-e-Silva et al. 2003) (Figure 5F); Carvalho-e-Silva et al. (2003), municipality of Quebrangulo, state of Alagoas, Brazil. Dendropsophus minutus species group (Faivovich et al. 2005) - Dendropsophus minutus (Peters, 1872) (Figure 5G): Bokermann (1963), municipality of Campo Grande, state of São Paulo, Brazil; Vizotto (1967), state of São Paulo, Brazil; Kenny (1968), Trinidad; Duellman (1978), Ecuador; Hero (1990), municipality of Manaus, state of Amazonas, Brazil; Heyer et al. (1990), municipality of Salesópolis, state of São Paulo, Brazil.

Specimens examined. Dendropsophus branneri: MUFAL 13943 (n $=15$, stages 28-31), municipality of Maceió, state of Alagoas, Brazil; CHUFPB 28052 ( $\mathrm{n}=15$, stages 38), municipality of Macaíba, state of Rio Grande do Norte, Brazil; CHUFPB 28513-14, 28513, 28575 ( $\mathrm{n}=$ 6, stages 30-36), municipality of João Pessoa, state of Paraíba, Brazil. Dendropsophus elegans: MUFAL 10131, $11260(\mathrm{n}=10$, stages 32-37), municipality of Ibateguara, state of Alagoas, Brazil. Dendropsophus haddadi: MUFAL 10167 ( $\mathrm{n}=8$, stages 30-37), municipality of Maceió, state of Alagoas, Brazil. Dendropsophus minutus: MUFAL 12479 ( $\mathrm{n}=$ 15, stages 30-34), municipality of Limoeiro de Anadia, state of Alagoas, Brazil; CHUFPB 28006-8 ( $\mathrm{n}=20$, stages 35-39), municipality of Macaíba, state of Rio Grande do Norte, Brazil. Dendropsophus nanus: MUFAL $12470(\mathrm{n}=1$, stage 40), municipality of Coruripe, state of Alagoas, Brazil; CHUFPB $28452(\mathrm{n}=4$, stages 36-39), municipality of Macaíba, state of Rio Grande do Norte, Brazil. Dendropsophus oliveirai: MUFAL 11259 ( $\mathrm{n}=4$, stages 35-39), municipality of São José da Tapera, state of Alagoas, Brazil; CHUFPB 28055 ( $\mathrm{n}=12$, stages 31-40), municipality of Macaíba, state of Rio Grande do Norte, Brazil. Dendropsophus soaresi: MUFAL $10206(\mathrm{n}=9$, stages 37-40), municipality of Coruripe, state of Alagoas, Brazil; CHUFPB 28056-59 ( $n=20$, stages 30-38), municipality of Macaíba, state of Rio Grande do Norte, Brazil. Dendropsophus studerae: MUFAL 15459-60 ( $\mathrm{n}=4$, stages 37-38), municipality of Quebrangulo, state of Alagoas, Brazil.

Characteristics: Dendropsophus decipiens species group - Body elliptical in dorsal view, triangular-depressed in lateral view. Snout rounded in dorsal view, oval in lateral view. Nostrils circular, anteriorly positioned much closer to tip of snout than to eyes. Eyes laterally positioned. Oral disc anterior, not emarginate. Marginal papillae arranged ventrolaterally, with a wide dorsal gap. LTRF 0/0. Spiracle sinistral. Vent tube dextral. Dorsal fin originating at tail-body junction, dorsal and ventral fins slightly arched. Tail length about $60 \%$ of total length, tail tip acute.

Dendropsophus leucophyllatus species group - Body ovoid, elongated in dorsal view, triangular-depressed in lateral view. Snout oval in dorsal and lateral views. Nostrils circular, anteriorly positioned, much closer to tip of snout than to eyes. Eyes laterally positioned. Oral disc anterior, not emarginate. Marginal papillae arranged ventrolaterally, with one dorsal gap and one pair of narrow ventrolateral gaps. LTRF 0/1. Spiracle sinistral. Vent tube dextral. Dorsal fin originating at tail-body 


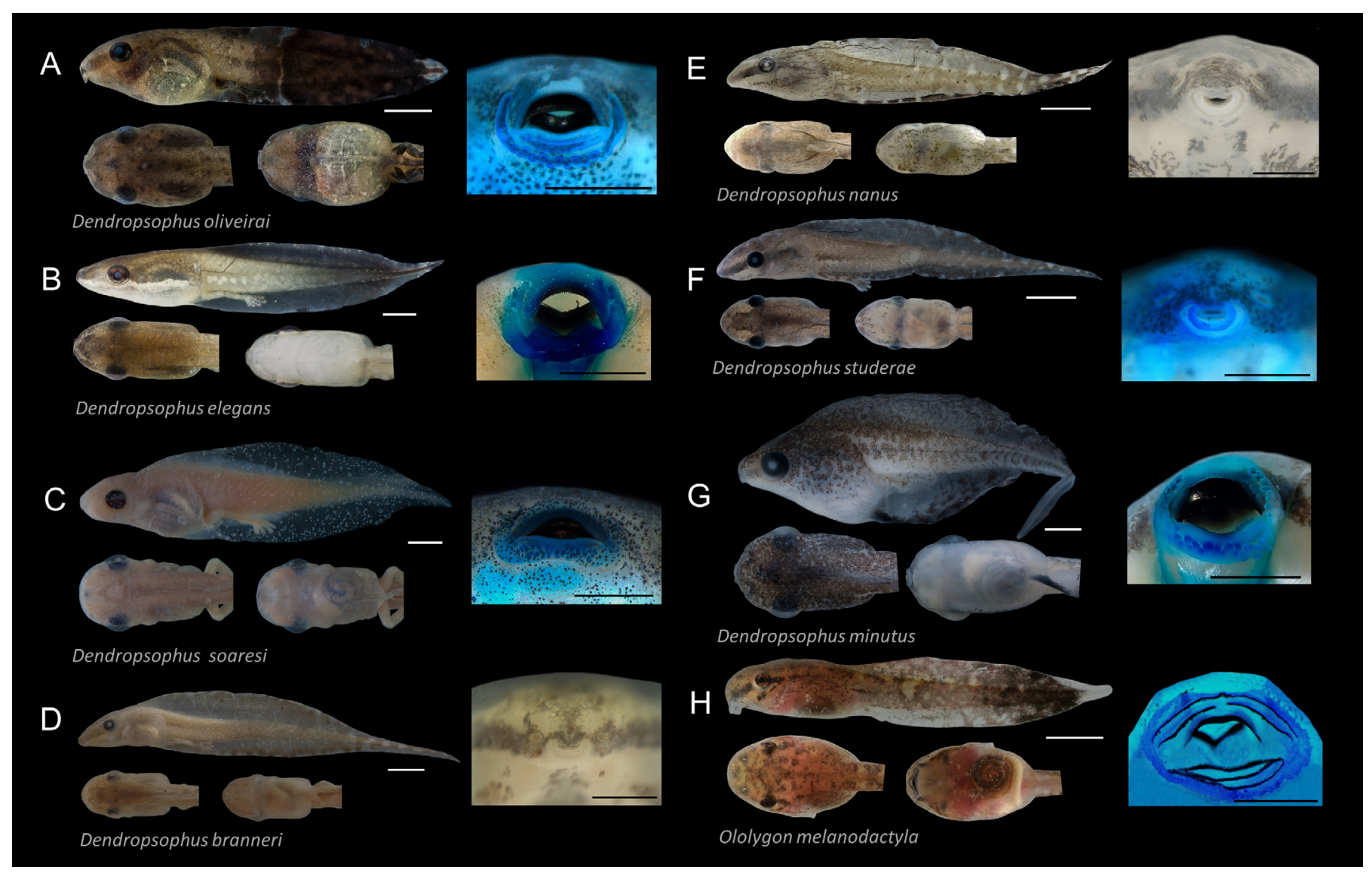

Figure 5. Lateral, dorsal and ventral views $(\mathrm{scale}=3 \mathrm{~mm})$ and oral disc $(\mathrm{scale}=1 \mathrm{~mm})$ of tadpoles occurring in the north of the Atlantic Forest.

junction, dorsal and ventral fins slightly arched. Tail length about $60 \%$ of total length, tail tip acute.

Dendropsophus marmoratus species group - Body ellipticalelongated in dorsal view, triangular-depressed in lateral view. Snout rounded in dorsal view, oval in lateral view. Nostrils circular, anteriorly positioned, much closer to tip of snout than to eyes. Eyes laterally positioned. Oral disc anterior, not emarginate. Marginal papillae arranged ventrolaterally, with one dorsal gap and one pair of narrow ventrolateral gaps. LTRF 0/1. Spiracle sinistral. Vent tube dextral. Dorsal fin originating at body, dorsal and ventral fins slightly arched. Tail length about $60 \%$ of total length, tail tip acute.

Dendropsophus microcephalus species group - Body ovoid, elongated in dorsal view, triangular-depressed in lateral view. Snout oval in dorsal and lateral views. Nostrils circular, anteriorly positioned, much closer to tip of snout than to eyes. Eyes laterally positioned. Oral disc anterior, not emarginate, modified in a protractile and conic-shaped tube. Marginal papillae absent. LTRF 0/0. Spiracle sinistral. Vent tube dextral. Dorsal fin originating at body or tail-body junction, dorsal fin slightly arched, ventral fin parallel to longitudinal axis of tail. Tail length about $60-70 \%$ of total length, tail tip acute, with flagellum.

Dendropsophus minutus species group - Body elliptical-elongated in dorsal view, triangular in lateral view. Snout rounded in dorsal view and truncate in lateral view. Nostrils circular, anteriorly positioned, much closer to tip of snout than to eyes. Eyes laterally positioned. Oral disc anterior, not emarginate. Marginal papillae arranged ventrolaterally, with a wide dorsal gap. LTRF 1/2. Spiracle sinistral. Vent tube dextral. Dorsal fin originating at body, dorsal and ventral fins arched. Tail length about $60 \%$ of total length, tail tip acute, with flagellum.

Notes: Tadpoles of $D$. minutus vary in LTRF, with the specimens analyzed here having $1 / 2$, while the specimens analyzed by Rossa-Feres \& Nomura (2006) exibiting 0/0,0/1 and $1 / 2$.

Ololygon Fitzinger, 1843

Species occurring in the region. Ololygon melanodactyla (Lourenço et al. 2014) (Figure 5H): Abreu et al. (2015b), municipality of Mata de São João, state of Bahia, Brazil. Ololygon skuki (Lima, Cruz, \& Azevedo, 2011) (Figure 6A): Rodrigues et al. (2017), municipality of Maceió, state of Alagoas, Brazil.

Specimens examined. Ololygon skuki: MUFAL 10200, 10161, $11041,11052,11062,11085$ ( $\mathrm{n}=17$, stages $31-40)$, municipality of Maceió, state of Alagoas, Brazil. Ololygon melanodactyla: UFBA 11878 ( $\mathrm{n}=1$, stage 31 ), municipality of Mata de São João, state of Bahia, located south of the São Francisco River. This locality was considered because although there are records for this species for the northern Atlantic Forest (Almeida et al. 2016), there are no tadpole specimens.

Characteristics: Body elliptical in dorsal view, globular-depressed in lateral view. Snout rounded in dorsal and lateral views. Nostrils circular, closer to eyes than to tip of snout or equally distant. Eyes dorsal. Oral disc ventral, not emarginated. Marginal papillae arranged 


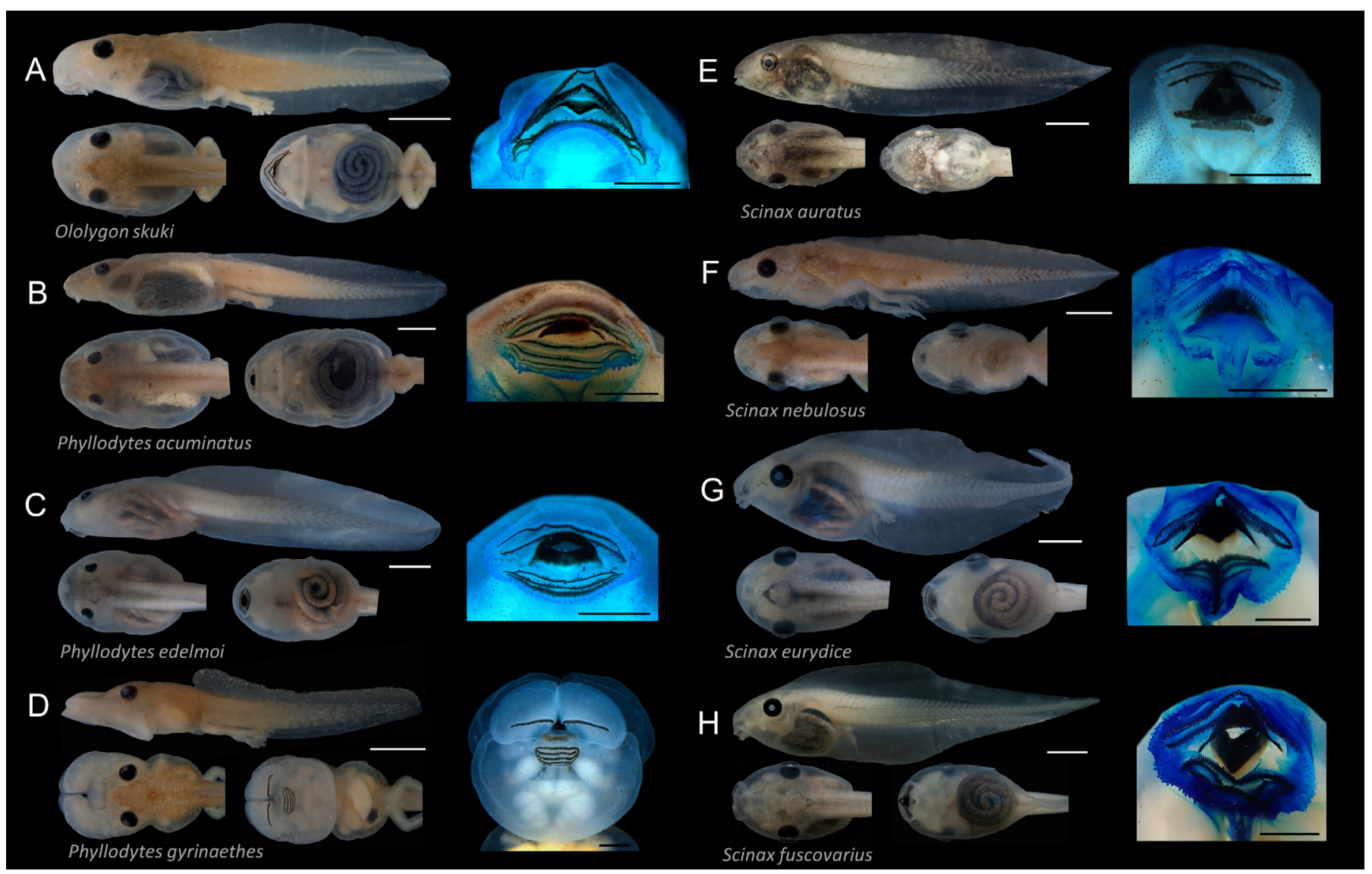

Figure 6. Lateral, dorsal and ventral views $(\mathrm{scale}=3 \mathrm{~mm})$ and oral disc $(\mathrm{scale}=1 \mathrm{~mm})$ of tadpoles occurring in the north of the Atlantic Forest.

ventrolaterally, with a wide dorsal gap. LTRF $2 / 3$ or $2(2) / 3$. Spiracle sinistral. Vent tube dextral. Dorsal fin originating at the end of body, dorsal and ventral fins parallel to longitudinal axis of tail. Tail length about $60 \%$ of total length, tail tip acute.

Phyllodytes Wagler, 1830

Species occurring in the region. Phyllodytes acuminatus Bokermann, 1966 (Figure 6B): Campos et al. (2014), municipality of Buíque, state of Pernambuco, Brazil. Phyllodytes brevirostris Peixoto and Cruz, 1988: Vieira et al. (2009), municipality of Cruz do Espírito Santo, state of Paraíba, Brazil. Phyllodytes edelmoi Peixoto et al. 2003 (Figure 6C): Peixoto et al. (2003), municipality of Maceió, state of Alagoas, Brazil. Phyllodytes gyrinaethes Peixoto et al. 2003 (Figure 6D): Peixoto et al. (2003), municipality of Murici, state of Alagoas, Brazil.

Specimens examined. Phyllodytes acuminatus: MUFAL 8384 (n $=11$, stages 30-40), municipality of Buíque, state of Pernambuco, Brazil. Phyllodytes brevirostris: exceptionally for this species, the morphological data were obtained from the literature because specimens were not available in the visited scientific collections (UFPB 4881, $\mathrm{n}=40$, stage 35 ), municipality of Cruz do Espírito Santo, state of Paraíba, Brazil. Phyllodytes edelmoi: MUFAL 3770 ( $\mathrm{n}=3$, stage 40), municipality of Maceió, state of Alagoas, Brazil. Phyllodytes gyrinaethes: MUFAL 13689 ( $\mathrm{n}=3$, stage 30), municipality of Murici, state of Alagoas, Brazil.
Characteristics: Body ovoid or elliptical in dorsal view, globulardepressed in lateral view. Snout rounded in dorsal view, sloped in lateral view. Nostrils circular, closer to tip of snout than to eyes. Eyes dorsal. Oral disc ventral, not emarginate. Marginal papillae arranged ventrolaterally, with a wide dorsal gap, absent in $P$. gyrinaethes. LTRF $2(2) / 4[5]$ or $1(1) / 5$, the latter only for $P$. gyrinaethes. Spiracle sinistral. Vent tube dextral. Dorsal fin originating at the end of body or at tailbody junction, dorsal fin arched or parallel to longitudinal axis of tail and ventral fins parallel to longitudinal axis of tail. Tail length $65 \%$ of total length, tail tip rounded.

Notes: Morphologically, P. gyrinaethes differs from all congeners by having a bell-shaped body in dorsal view, wider posteriorly and with lateral reentrances in the midbody; snout flat with a deep indentation at the anterior margin in dorsal view. Peixoto et al. (2003) reported specimens of $P$. edelmoi with LTRF 2(2)/5[6], while the specimens analyzed in the present study had LTRF $2(2) / 5$.

Scinax Wagler, 1830

Species occurring in the region. Scinax rostratus species group (Faivovich et al. 2005) - Scinax auratus (Wied-Neuwied, 1821). Although this species was included in the Scinax ruber clade, it was not currently associated with any species group by Faivovich et al. (2005). Here this species was treated as related to $S$. rostratus group by overall morphological resemblance of their tadpoles, and for sharing some diagnostic larval characteristics with this group 
(Faivovich 2002), see characteristics; Figure 6E): Alves et al. (2004), municipality of Quebrangulo, state of Alagoas, Brazil. Scinax nebulosus (Spix, 1824) (Figure 6F): Gomes et al. (2014), municipality of Cabo de Santo Agostinho, state of Pernambuco, Brazil. Species of the Scinax unassigned to a species group (previously in the "Scinax ruber clade", Faivovich et al. 2005) - Scinax eurydice (Bokermann, 1968) (Figure 6G): Wogel et al. (2000), municipality of Saquarema, state of Rio de Janeiro, Brazil. Scinax fuscovarius (Lutz, 1925) (Figure 6H): Vizotto (1967), state of São Paulo, Brazil; Fabrezi \& Vera (1997), Argentina; Schulze et al. (2015), Bolivia. Scinax fuscomarginatus (Lutz, 1925) (Figure 7A): Vizotto (1967), state of São Paulo, Brazil. Scinax pachycrus (Miranda-Ribeiro, 1937) (Figure 7B): Carneiro et al. (2004), municipality of Santa Terezinha, state of Bahia, Brazil. Scinax $x$-signatus (Spix, 1824) (Figure 7C): Leon (1975), Venezuela; Lynch (2006), Colombia.

Specimens examined. Scinax auratus: MUFAL $15461(\mathrm{n}=10$, stages 35-37), municipality of Quebrangulo, state of Alagoas, Brazil. Scinax eurydice: MUFAL 13497 ( $\mathrm{n}=3$, stages 36-37), municipality of Maceió, state of Alagoas, Brazil. Scinax fuscovarius: MUFAL 13936 (n $=15$, stages 30-32), municipality of Satuba, state of Alagoas, Brazil. Scinax fuscomarginatus: CHUFPB $28033(\mathrm{n}=15$, stages 32-37), municipality of Macaíba, state of Rio Grande do Norte, Brazil. Scinax nebulosus: MUFAL $3785(\mathrm{n}=2$, stages 30-40), municipality of Maceió; MUFAL $13912(\mathrm{n}=5$, stages 37-38), municipality of Limoeiro de
Anadia; both from the state of Alagoas, Brazil. Scinax pachycrus: MUFAL 15449 ( $\mathrm{n}=6$, stages 35-36), municipality of Água Branca, state of Alagoas, Brazil; CHUFPB 28034-35 ( $\mathrm{n}=11$, stages 30-32), municipality of Macaíba, state of Rio Grande do Norte, Brazil. Scinax x-signatus: MUFAL $11023(\mathrm{n}=2$, stage 30), municipality of Maceió, state of Alagoas, Brazil; CHUFPB 28497 ( $n=1$, stage 25), municipality of João Pessoa, state of Paraíba, Brazil; CHUFPB 28037 ( $n=10$, stages 35-40), municipality of Macaíba, state of Rio Grande do Norte, Brazil.

Characteristics: Scinax rostratus species group - Body elliptical in dorsal view, triangular-depressed in lateral view. Snout rounded in dorsal view, oval in lateral view. Nostrils circular, slightly closer to eyes than to tip of snout. Eyes lateral. Oral disc anteroventral, two emarginations on lower margin, labial arm present. Marginal papillae arranged ventrolaterally, with a wide dorsal gap, absent at the labial arm. LTRF 2(2)/3(1), with the P3 located at end of labial arm. Spiracle sinistral. Vent tube dextral. Dorsal fin originating at posterior third of body, dorsal fin and ventral fins slightly arched. Tail length about $65 \%$ of total length, tail tip acute.

Scinax ruber clade - Body elliptical in dorsal view, triangular or triangular-depressed in lateral view. Snout rounded in dorsal view, oval or truncate in lateral view. Nostrils oval, closer to tip of snout than to eyes. Eyes lateral. Oral disc anteroventral, two emarginations on lower margin. Marginal papillae arranged ventrolaterally, with a wide dorsal gap. LTRF 2(2)/3 [exception in S. pachycrus: 2(2)/3(1)]. Spiracle

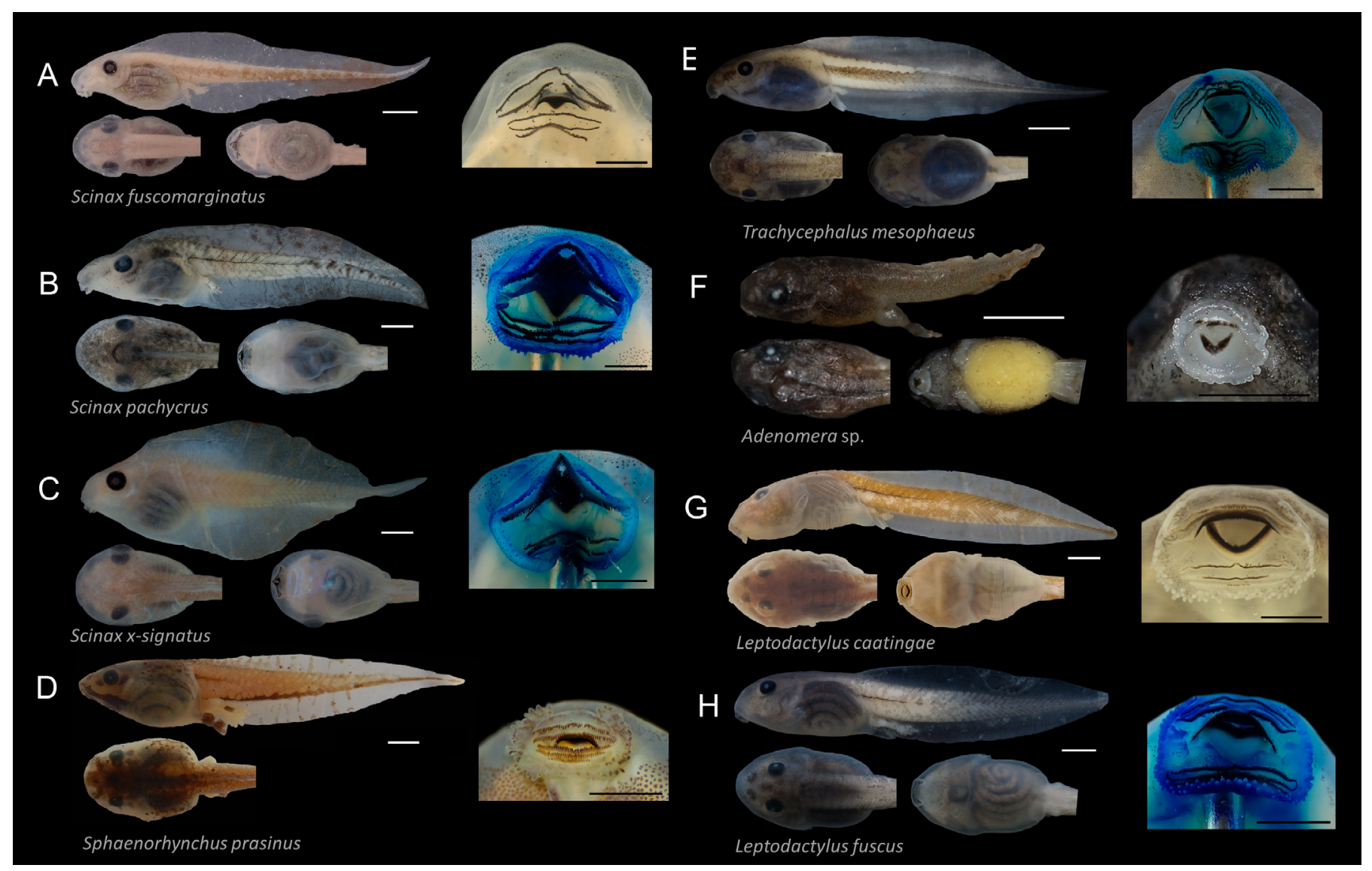

Figure 7. Lateral, dorsal and ventral views $(\mathrm{scale}=3 \mathrm{~mm})$ and oral disc $(\mathrm{scale}=1 \mathrm{~mm})$ of tadpoles occurring in the north of the Atlantic Forest. 
sinistral. Vent tube dextral. Dorsal fin originating at the middle or end of body, dorsal and ventral fins arched. Tail length about $70 \%$ of total length, tail tip acute.

Sphaenorhynchus Tschudi, 1838

Species occurring in the region. Sphaenorhynchus prasinus Bokermann 1973 (Figure 7D): Bokermann (1973), municipality of Ilhéus, state of Bahia, Brazil.

Specimens examined. Sphaenorhynchus prasinus: MZUESC (these tadpoles were obtained in a recent sampling, right on with the closing of Universities during COVID-19 pandemic, preventing us from getting voucher numbers for these specimens, $n=10$, stages $33-38$ ), municipality of Ilhéus, state of Bahia, Brazil, located at south of the São Francisco River. They were included because although there are records of this species for the northern Atlantic Forest (Almeida et al. 2016), there are no tadpole specimens.

Characteristics: Body ovoid in dorsal view, triangular-depressed in lateral view. Snout rounded in dorsal view, sloped in lateral view. Nostrils reniform, closer to tip of snout than to eyes. Eyes lateral. Oral disc anteroventral, not emarginate. Marginal papillae arranged ventrolaterally, with a wide dorsal gap, few large marginal papillae (highlighted papillae) on the anterolateral and posterolateral margins (large papillae about twice the size of the small papillae and alternating among them). LTRF 2(2)/3(1). Spiracle sinistral. Vent tube medial. Dorsal fin originating at tail-body junction, dorsal fin parallel to longitudinal axis of tail and ventral fin slightly arched. Tail length about $60 \%$ of total length, tail tip acute.

Trachycephalus Tschudi, 1838

Species occurring in the region. Trachycephalus mesophaeus (Hensel, 1867) (Figure 7E): Lutz (1973), municipality of Saquarema, state of Rio de Janeiro, Brazil; Carvalho-e-Silva et al. (2002), municipality of Rio de Janeiro, state of Rio de Janeiro, and municipality of Ubatuba, state of São Paulo, Brazil; Prado et al. (2003), municipality of Ubatuba, state of São Paulo, and municipality of Cariacica, state of Espírito Santo, Brazil.

Specimens examined. Trachycephalus mesophaeus: MUFAL 15457 ( $\mathrm{n}=6,31-34)$, municipality of Porto Seguro, state of Bahia, Brazil, located at south of the São Francisco River. They were included because although there are records of this species for the northern Atlantic Forest (Almeida et al. 2016), there are no tadpole specimens.

Characteristics: Body elliptical in dorsal view, triangular-depressed in lateral view. Snout rounded in dorsal view, sloped in lateral view. Nostrils circular, closer to eyes than to tip of snout. Eyes lateral. Oral disc anteroventral, not emarginate. Marginal papillae arranged ventrolaterally, with a wide dorsal gap. LTRF 4(1,2,4)/6(1). Spiracle sinistral. Vent tube medial. Dorsal fin originating at tail-body junction, dorsal and ventral fins slightly arched. Tail length nearly $70 \%$ of total length, tail tip acute, with flagellum.

Family Leptodactylidae

Adenomera Steindachner, 1867

Species occurring in the region. Adenomera aff. hylaedactyla (Cope, 1868): Kokubum \& de-Souza (2008), municipality of Rio Branco, state of Acre, Brazil; Menin et al. (2009), municipality of Manaus, state of Amazonas, Brazil.

Specimens examined. Adenomera sp.: LHUFCG $0110(n=1$, stage 36; Figure 7F), northeastern Brazil. The populations occurring in the Atlantic Forest domain are probably an undescribed taxon and there are no tadpole specimens available, so they were not included in the key. However, due to the phylogenetically conserved morphology of these endotrophic tadpoles, we present here a general characterization for the genus based on specimens obtained in the Cerrado biome.

Characteristics: Body ovoid in dorsal view, oval-depressed in lateral view. Snout rounded in dorsal view, oval in lateral view. Nostrils circular, located closer to tip of snout than to eyes. Eyes dorsal. Oral disc ventral, not emarginate. Marginal papillae with broad dorsal gap. LTRF 0/0. No spiracle. Vent tube medial. Dorsal fin originating at tail-body junction, dorsal fin and ventral fin parallel to longitudinal axis of tail. Tail length approximately $65 \%$ of total length, tail tip acute.

Leptodactylus Fitzinger, 1826

Species occurring in the region. Leptodactylus fuscus species group (de Sá et al. 2014) - Leptodactylus caatingae (Magalhães et al. 2013a) (Figure 7G): municipality of Macaíba, state of Rio Grande do Norte, Brazil. Leptodactylus fuscus (Schneider, 1799) (Figure 7H): Kenny (1968), Trinidad; Lescure (1972), French Guiana; Hero (1990), municipality of Manaus, state of Amazonas, Brazil; Rada-deMartínez (1990), Venezuela; Lynch (2006), Colombia. Leptodactylus mystaceus (Spix, 1824) (Figure 8A): Duellman (1978), Equador; Hero (1990), municipality of Manaus, state of Amazonas, Brazil; Heyer (1978), Ecuador. Leptodactylus troglodytes Lutz, 1926 (Figure 8B): Cascon \& Peixoto (1985), municipality of Cabaceiras, state of Paraíba, Brazil; Kokubum \& Maciel (2009), municipality of Cocos, state of Bahia, and municipality of Buritizeiro, state of Minas Gerais, Brazil. Leptodactylus latrans species group (de Sá et al. 2014) - Leptodactylus macrosternum Miranda-Ribeiro, 1926 (Figure 8C): Dixon \& Staton (1976), Venezuela. Leptodactylus melanonotus species group (de Sá et al. 2014) - Leptodactylus natalensis Lutz, 1930 (Figure 8D): Oliveira \& Lírio-Júnior (2000), municipality of São Cristovão, state of Sergipe, Brazil; Dubeux et al. (2020a), municipality of Teotônio Vilela, state of Alagoas, and municipality of Ribeirão, Pernambuco state, Brazil. Leptodactylus pentadactylus species group (de Sá et al. 2014) - Leptodactylus vastus Lutz, 1930 (Figure 8E): Vieira et al. (2007a), municipality of João Pessoa, state of Paraíba, Brazil; Schulze et al. (2015), Bolivia.

Specimens examined. Leptodactylus caatingae: CHUFPB 27232, 28001, 28217 ( $\mathrm{n}=20$, stage 36), municipality of Macaíba, state of Rio Grande do Norte, Brazil. Leptodactylus fuscus: CHUFPB 28013 ( $\mathrm{n}=7$, stages 36-40), municipality of Macaíba, state of Rio Grande do Norte, Brazil; MUFAL 13938 ( $\mathrm{n}=10$, stages 35-39), municipality of Maceió, state of Alagoas, Brazil; CHUFPE-A 1129 ( $\mathrm{n}=20$, stages 34-36), municipality of Recife, state of Pernambuco, Brazil. Leptodactylus macrosternum: MUFAL 11022 ( $\mathrm{n}=8$, stage 31 ), municipality of Maceió, state of Alagoas, Brazil; CHUFPB 28002-5 (n $=20$, stages 32-34), municipality of Macaíba, state of Rio Grande do Norte, Brazil. Leptodactylus mystaceus: MUFAL 13408 ( $\mathrm{n}=16$, stages 34-40), municipality of Maceió, state of Alagoas, Brazil. Leptodactylus natalensis: MUFAL12465 ( $\mathrm{n}=10$, stages 36-37), municipality of Teotônio Vilela, state of Alagoas, Brazil. Leptodactylus troglodytes: CHUFPB 28071 ( $\mathrm{n}=8$, stages 35-39), municipality of Macaíba, and CHUFPB 28208 ( $\mathrm{n}=3$ stage 35), municipality of Nísia Floresta; both in state of Rio Grande do Norte, Brazil; MUFAL 12459 ( $n=10$, stages 28-31), municipality of Junqueiro, state of Alagoas, Brazil. Leptodactylus vastus: MUFAL $10216(\mathrm{n}=9$, stages 31-36), municipality of Maceió, and MUFAL 10148 ( $n=2$, stage 40), municipality of Satuba; 


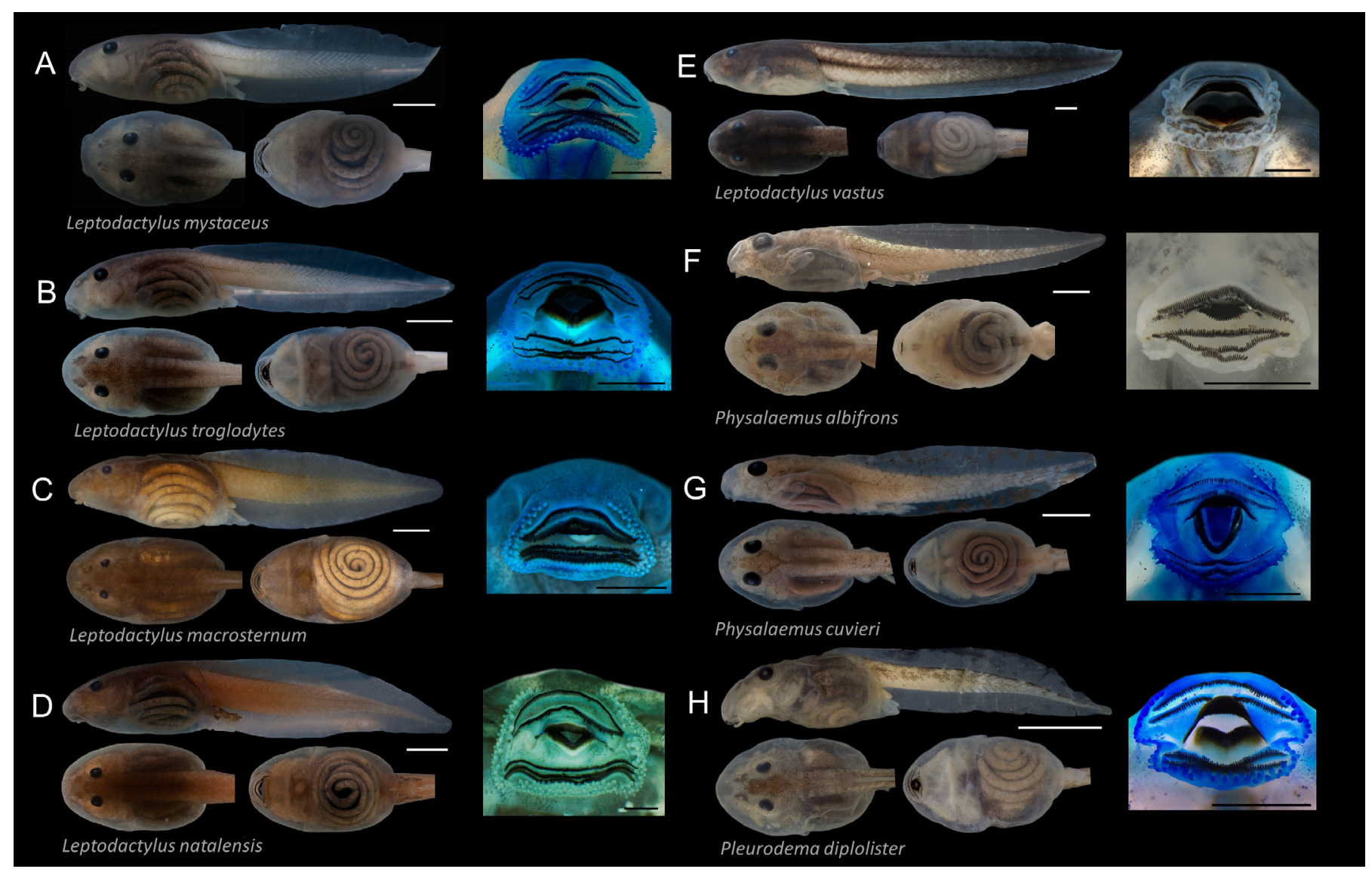

Figure 8. Lateral, dorsal and ventral views $(\mathrm{scale}=3 \mathrm{~mm})$ and oral disc $(\mathrm{scale}=1 \mathrm{~mm})$ of tadpoles occurring in the north of the Atlantic Forest.

both from the state of Alagoas, Brazil; CHUFPB 28603 ( $\mathrm{n}=8$, stage 29), municipality of João Pessoa, state of Paraíba, Brazil; CHUFPB 28066-69 ( $\mathrm{n}=20$, stages 31-40), municipality of Macaíba, state of Rio Grande do Norte, Brazil.

Characteristics: Leptodactylus fuscus species group - Body elliptical or ovoid in dorsal view, globular-depressed in lateral view. Snout oval or rounded in dorsal view, oval in lateral view. Nostrils circular, generally located closer to tip of snout than to eyes. Eyes dorsal. Oral disc anteroventral, not emarginate. Marginal papillae arranged ventrolaterally, with a wide dorsal gap, anterior margin of oral disc totally fused with body wall. LTRF 2(2)/3(1). Spiracle sinistral. Vent tube medial. Dorsal fin originating at tail-body junction, dorsal and ventral fins slightly arched. Tail length approximately $60 \%$ of total length, tail tip acute.

Leptodactylus latrans species group - Body ovoid, elongated in dorsal view, globular-depressed in lateral view. Snout oval in dorsal and lateral views. Nostrils circular, generally located closer to tip of eyes than to snout. Eyes dorsal. Oral disc anteroventral, not emarginate. Marginal papillae arranged ventrolaterally, with a wide dorsal gap, anterior margin of oral disc totally fused with body wall. LTRF 2/3. Spiracle sinistral. Vent tube medial. Dorsal fin originating at tail-body junction, dorsal and ventral fins slightly arched. Tail length approximately $60 \%$ of total length, tail tip slightly rounded.

Leptodactylus melanonotus species group - Body oval, elongated in dorsal view, globular-depressed in lateral view. Snout oval in dorsal and lateral views. Nostrils circular, located closer to eyes than to snout. Eyes dorsal. Oral disc ventral, not emarginate, anterior margin of oral disc totally fused with body wall. Marginal papillae arranged ventrolaterally, with a wide dorsal gap. LTRF 2/3. Spiracle sinistral. Vent tube medial. Dorsal fin originating at tail-body junction, dorsal and ventral fins slightly arched. Tail length approximately $60 \%$ of total length, tail tip acute.

Leptodactylus pentadactylus species group - Body oval, elongated in dorsal view, globular-depressed in lateral view. Snout oval in dorsal and lateral views. Nostrils circular, located almost midway between the eyes and the snout tip. Eyes dorsal. Oral disc anteroventral, not emarginate, anterior margin of oral disc totally fused with body wall. Marginal papillae arranged ventrolaterally, with a wide dorsal gap. LTRF 1/2(1). Spiracle sinistral. Vent tube medial. Dorsal fin originating at tail-body junction, dorsal and ventral fins parallel to longitudinal axis of tail. Tail length approximately $70 \%$ of total length, tail tip acute.

Physalaemus Fitzinger, 1826

Species occurring in the region. Physalaemus albifrons (Spix, 1824) (Figure 8F): Oliveira et al. (2010), municipality of Brotas de Macaúbas, state of Bahia, Brazil. Physalaemus caete Pombal \& Madureira 1997: Pombal \& Madureira (1997), municipality of Passo de Camaragibe, state of Alagoas, Brazil. Physalaemus cuvieri Fitzinger, 1826 (Figure 8G): Bokermann (1962), municipality of Diadema, state of São Paulo, Brazil; Cei (1980), Argentina; Heyer et al. (1990), municipality of Boracéia, state of São Paulo, Brazil. 
Specimens examined. Physalaemus albifrons: CHUFPB 28453 (n $=10$, stages 37-40), municipality of Macaíba, state of Rio Grande do Norte, Brazil; UFBA 10013 ( $\mathrm{n}=8$, stages 33-37), municipality of Pilão Arcado, state of Bahia, Brazil. Physalaemus caete: exceptionally for this species, the morphological data were obtained from the literature because specimens were not available in the visited scientific collections (MNRJ 18280, $\mathrm{n}=1$, stage 28), municipality of Passo do Camaragibe, state of Alagoas, Brazil. Physalaemus cuvieri: MUFAL 10208 ( $\mathrm{n}=11$, stages 34-40), municipality of Coruripe, state of Alagoas, Brazil; CHUFPB $28025(n=20$, stages 37-40), municipality of Macaíba, state of Rio Grande do Norte, Brazil.

Characteristics: Body ovoid in dorsal view, globular-depressed in lateral view. Snout oval in dorsal and lateral views. Eyes dorsal. Nostrils circular, generally located closer to eyes than to tip of snout. Oral disc ventral, emarginate laterally, anterior margin of oral disc totally fused with body wall. Marginal papillae with wide dorsal gap, narrow ventromedial gap, and two small ventrolateral gaps (not ventromedial and ventrolateral gaps in $P$. caete). LTRF 2(2)/3(1)[2]. Spiracle sinistral. Vent tube dextral. Dorsal fin originating at tail-body junction, dorsal fin arched and ventral fin parallel to longitudinal axis of tail. Tail length approximately $60 \%$ of total length, tail tip acute.

Notes: Pombal \& Madureira (1997) described the vent tube of $P$. caete as medial even though their illustration shows the tube sloping towards the right side, which is characteristic of a dextral opening. The P. cuvieri tadpoles characterized by Rossa-Feres \& Nomura (2006) from Nova Itapirema, state of São Paulo, Brazil, differs from those studied here by having a medial vent tube opening. Bokermann (1962) reported a LTRF 2(2)/3 for P. cuvieri tadpoles from Posto Jacaré, state of Mato Grosso, Brazil.

Pleurodema Tschudi, 1838

Species occurring in the region. Pleurodema diplolister (Peters, 1870) (Figure 8H): Peixoto (1982), municipality of Mossoró, state of Rio Grande do Norte, Brazil.

Specimens examined. Pleurodema diplolister: CHUFPB 28026-27 ( $\mathrm{n}=12$, stages 32-40), municipality of Macaíba, state of Rio Grande do Norte, Brazil; MZFS 326 ( $\mathrm{n}=4$, stages 35-36), municipality of Feira de Santana, state of Bahia, Brazil.

Characteristics: Body oval, elongated in dorsal view, globulardepressed in lateral view. Snout oval in dorsal view, sloped in lateral view. Nostrils circular or oval, generally located at midway between the eyes and tip of snout. Eyes dorsal. Oral disc anteroventral, emarginate laterally. Marginal papillae arranged ventrolaterally, anterior margin of oral disc totally fused with body wall. Marginal papillae with wide dorsal gap. LTRF 2(2)/3(1). Spiracle sinistral. Vent tube medial. Dorsal fin originating on the body and slightly arched, and ventral fin parallel to longitudinal axis of tail. Tail length approximately $65 \%$ of total length, tail tip acute.

Notes: The tadpoles of $P$. diplolister described by Peixoto (1982) from Mossoró, state of Rio Grande do Norte, Brazil, differ from those studied here by having a sinistral vent tube opening, although the illustration clearly shows a dextral opening.

Pseudopaludicola Miranda-Ribeiro, 1926

Species occurring in the region. Pseudopaludicola mystacalis (Cope, 1887) (Figure 9A): Schulze et al. (2015), Bolivia. Pseudopaludicola pocoto Magalhães et al. 2014 (Figure 9B): Magalhães et al. (2014), municipality of Macaíba, state of Rio Grande do Norte, Brazil.
Specimens examined. Pseudopaludicola mystacalis: CHUFPB $28030(n=10$, stages 30-40), municipality of Arês, state of Rio Grande do Norte, Brazil; MUFAL 13956 ( $\mathrm{n}=1$, stage 40), municipality of Satuba, state of Alagoas, Brazil. Pseudopaludicola pocoto: CHUFPB 28021-22 ( $\mathrm{n}=20$, stages 36-40), municipality of Macaíba; CHUFPB 29209 ( $n=20$, stages 30-40), municipality of Nísia Floresta; both in state of Rio Grande do Norte, Brazil.

Characteristics: Body elliptical or ovoid in dorsal view, globulardepressed in lateral view. Snout rounded or oval in dorsal view, oval in lateral view. Nostrils circular, located closer to eyes than to tip of snout. Eyes dorsal. Oral disc ventral, emarginate laterally. Marginal papillae with wide dorsal gap and two small ventrolateral gaps, anterior margin of oral disc totally fused with body, LTRF 2(2)/2. Spiracle sinistral. Vent tube dextral. Dorsal fin originating at tail-body junction, dorsal fin arched and ventral fin parallel to longitudinal axis of tail. Tail length approximately $60 \%$ of total length, tail tip acute.

\section{Family Microhylidae}

Chiasmocleis Méhely, 1904

Species occurring in the region. Chiasmocleis alagoana Cruz, Caramaschi \& Freire, 1999 (Figure 9C): Nascimento \& Skuk (2006), municipality of Maceió, state of Alagoas, Brazil.

Specimens examined. Chiasmocleis alagoana: MUFAL $9785(\mathrm{n}=4$, stages 30-31), municipality of Maceió, state of Alagoas, Brazil.

Characteristics: Body rounded in dorsal view, triangular-depressed in lateral view. Snout rounded in dorsal view and truncate in lateral view. Nostrils absent in early development stages. Eyes lateral. Oral disc lacking keratinized structures, semicircular lips flaps over oral opening. Marginal papillae absent. Spiracle long, ventrally positioned, posteroventrally directed, reaching and overlapping the vent tube opening. Vent tube medial. Dorsal fin originating at posterior end of body, dorsal and ventral fins arched. Tail length approximately $60 \%$ of total length, tail tip acute with flagellum.

\section{Dermatonotus Méhely, 1904}

Species occurring in the region. Dermatonotus muelleri (Boettger, 1885) (Figure 9D): Cei (1980) and Lavilla (1992), Argentina; Vizotto (1967), state of São Paulo, Brazil; Schulze et al. (2015), Bolivia.

Specimens examined. Dermatonotus muelleri: MUFAL 13687, $12472(\mathrm{n}=3$, stages 35-37), municipality of Coruripe, MUFAL 13874 ( $\mathrm{n}=7$, stages 30-38), municipality of Arapiraca, and MUFAL 13910 $(\mathrm{n}=15$, stages $30-35)$, municipality of Delmiro Gouveia; all from the state of Alagoas, Brazil; CHUFPB 28083-90 $(n=20$, stages 38-40), municipality of Macaíba, state of Rio Grande do Norte, Brazil.

Characteristics: Body rounded in dorsal view, triangular in lateral view. Snout rounded in dorsal view, truncate in lateral view. Nostrils absent in early development stages. Eyes lateral. Oral disc lacking keratinized structures, square lip flaps over oral opening. Marginal papillae absent. Spiracle long, tubular, ventrally positioned, extending posteroventrally reaching and overlapping vent tube. Vent tube medial. Dorsal fin originating on tail, dorsal and ventral fins arched; dorsal fin lacking pigmentation posteriorly. Tail length about $60 \%$ of total length, tail tip acute.

Elachistocleis Parker, 1927

Species occurring in the region. Elachistocleis cesarii (MirandaRibeiro, 1920) (Figure 9E): Magalhães et al. (2012), municipality of Macaíba, state of Rio Grande do Norte, Brazil. 


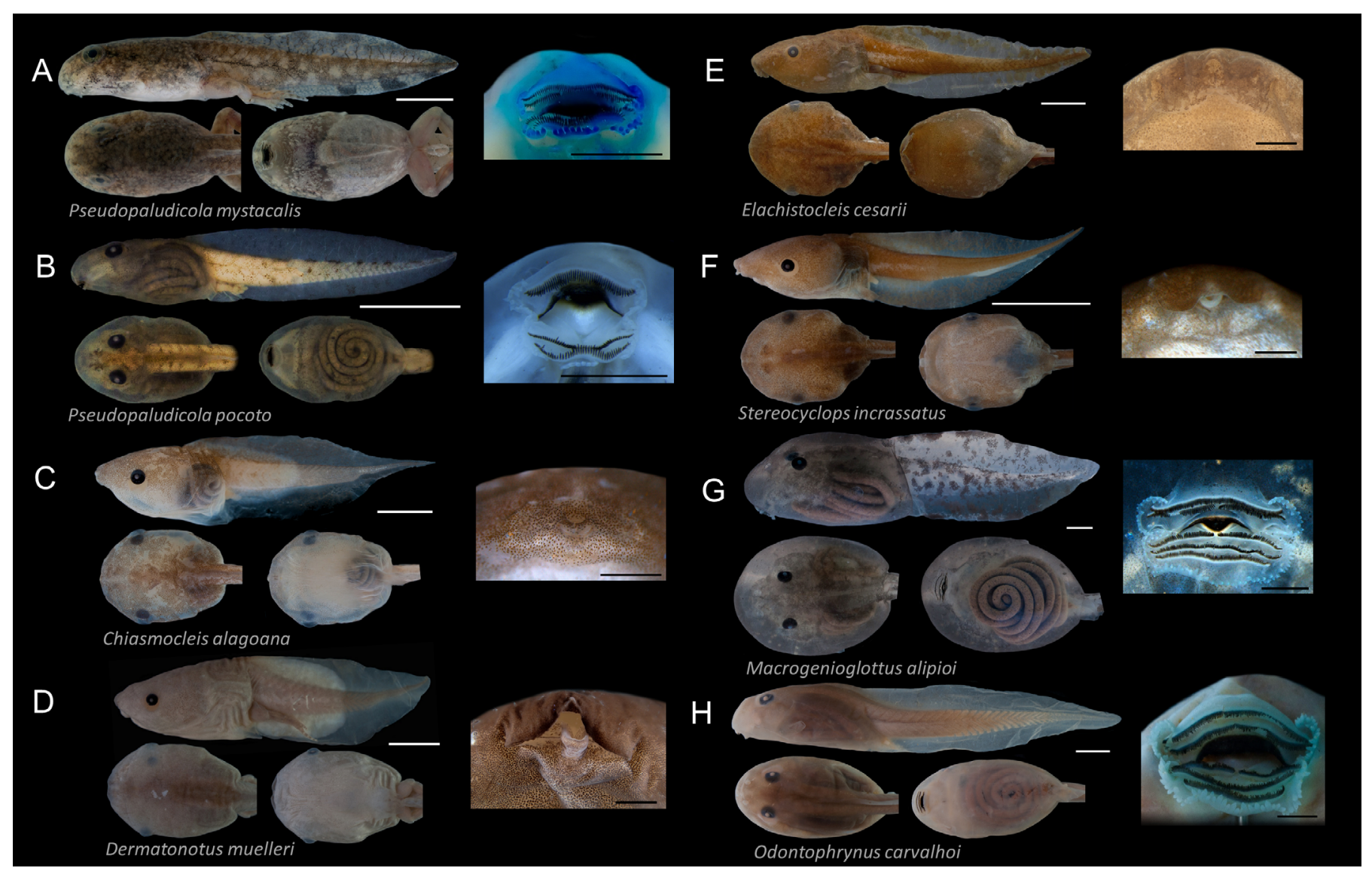

Figure 9. Lateral, dorsal and ventral views $(\mathrm{scale}=3 \mathrm{~mm})$ and oral disc $(\mathrm{scale}=1 \mathrm{~mm})$ of tadpoles occurring in the north of the Atlantic Forest.

Specimens examined. Elachistocleis cesarii: CHUFPB 28009-12 ( $n=20$, stage 28), municipality of Macaíba, state of Rio Grande do Norte, Brazil.

Characteristics: Body rounded in dorsal view, triangular-depressed in lateral view. Snout rounded in dorsal view, truncate in lateral view. Nostrils absent in early development stages. Eyes lateral. Oral disc lacking keratinized structures, rounded lip flaps over and covering the oral opening. Marginal papillae absent. Spiracle long, tubular, ventrally positioned, extending posteroventrally reaching and overlapping the vent tube. Vent tube medial. Dorsal fin originating at tail-body junction, dorsal and ventral fins arched. Tail length about $60 \%$ of total length, tail tip acute.

Stereocyclops Cope, 1870

Species occurring in the region. Stereocyclops incrassatus Cope, 1870 (Figure 9F): Wogel et al. (2000), municipality of Saquarema, state of Rio de Janeiro, Brazil.

Specimens examined. Stereocyclops incrassatus: MUFAL 10126 ( $\mathrm{n}=9$, stage 30-31), municipality of Marechal Deodoro, state of Alagoas, Brazil.

Characteristics: Body rounded in dorsal view, triangular-depressed in lateral view. Snout rounded in dorsal view, truncate in lateral view. Nostrils absent in early development stages. Eyes lateral. Oral disc lacking keratinized structures, square lip flaps over and covering the oral opening. Marginal papillae absent. Spiracle long, tubular, ventrally positioned, extending posteroventrally reaching and overlapping the vent tube. Vent tube medial. Dorsal fin originating at tail-body junction, dorsal and ventral fins slightly arched. Tail length about $60 \%$ of total length, tail tip acute with flagellum.

\section{Family Odontophrynidae}

Macrogenioglottus Carvalho, 1946

Species occurring in the region. Macrogenioglottus alipioi Carvalho, 1946 (Figure 9G): Abravaya \& Jackson (1978), municipality of Santa Teresa, state of Espírito Santo, Brazil; Lisboa et al. (2011), municipality of Maceió, state of Alagoas, Brazil.

Specimens examined. Macrogenioglottus alipioi: MUFAL 10166 and $12468(\mathrm{n}=7$, stages $31-34)$, municipality of Maceió, and MUFAL $13952(n=3$, stages 30-37) municipality of Satuba; both from the state of Alagoas, Brazil.

Characteristics: Body rounded in dorsal view and globular in lateral view. Snout rounded in dorsal view, oval in lateral view. Nostrils circular, located between eyes and tip of snout. Eyes dorsal. Oral disc ventral, emarginate laterally. Marginal papillae arranged ventrolaterally, with a wide dorsal gap. LTRF 2(2)/3(1). Spiracle sinistral. Vent tube dextral. Dorsal fin originating on posterior third of the body, dorsal fin arched and ventral fin slightly arched. Tail length approximately $50 \%$ of total length, tail tip acute.

Odontophrynus Reinhardt and Lütken, 1862

Species occurring in the region. Odontophrynus carvalhoi Savage \& Cei, 1965 (Figure 9H): Caramaschi (1979), municipality of Maracás, state of Bahia, Brazil; Santos et al. (2017), municipalities of São Domingos and Sítio d'Abadia; both from the state of Goiás, Brazil; Costa et al. (2017), municipality of Triunfo, state of Pernambuco, Brazil. 
Specimens examined. Odontophrynus carvalhoi: MUFAL 10717 ( $\mathrm{n}=$ 15, stages 30-40), municipality of Triunfo, state of Pernambuco, Brazil.

Characteristics: Body elliptical in dorsal view, globular-depressed in lateral view. Snout oval in dorsal and lateral views. Nostrils reniform, closer to eyes than to tip of snout. Eyes dorsal. Oral disc anteroventral, emarginate laterally. Marginal papillae arranged ventrolaterally, with a wide dorsal gap. LTRF 2/3(1). Spiracle sinistral. Vent tube dextral. Dorsal fin originating at posterior portion of body, dorsal fin arched and ventral fin parallel to longitudinal axis of tail. Tail length about $60 \%$ of total length, tail tip acute.

Proceratophrys Miranda-Ribeiro, 1920

Species occurring in the region. Proceratophrys cristiceps (Müller, 1883) (Figure 10A): Vieira et al. (2007b), municipality of São João do Cariri, state of Paraíba, Brazil. Proceratophrys renalis (MirandaRibeiro, 1920) (Figure 10B): Nascimento et al. (2010), municipality of Maceió, state of Alagoas, Brazil.

Specimens examined. Proceratophys cristiceps: CHUFPB 28093 (n $=15$, stages 35-38), municipality of Macaíba, state of Rio Grande do Norte, Brazil. Proceratophrys renalis: MUFAL 12501 ( $\mathrm{n}=16$, stages 30-39), municipality of Murici, state of Alagoas, Brazil.

Characteristics: Body ovoid in dorsal view, globular-depressed in lateral view. Snout oval in dorsal and lateral views. Nostrils reniform, closer to eyes than to tip of snout. Eyes dorsal. Oral disc ventral, emarginate laterally. Marginal papillae arranged ventrolaterally, with a wide dorsal gap. LTRF 2(2)/3(1). Spiracle sinistral. Vent tube dextral. Dorsal fin originating at posterior portion of body, dorsal fin arched and ventral fin parallel to longitudinal axis of tail. Tail length about $60 \%$ of total length, tail tip acute.

\section{Family Phyllomedusidae}

Hylomantis Peters, 1873 "1872"

Species occurring in the region. Hylomantis granulosa (Cruz, 1989) (Figure 10C): Nascimento \& Skuk (2007), municipality of Maceió, state of Alagoas, Brazil.
Specimens examined. Hylomantis granulosa: MUFAL 13948 , MUFAL $13950(n=15$, stages 30-37), municipality of Satuba, state of Alagoas, Brazil.

Characteristics: Body elliptical-elongated in dorsal view, triangularobtuse in lateral view. Snout oval in dorsal and lateral view. Nostrils circular, located anteriorly, closer to tip of snout than to eyes. Eyes lateral. Oral disc anterior, posterior margin visible in dorsal view, not emarginate. Marginal papillae arranged lateroventrally, with a wide dorsal gap. LTRF 2(2)/3. Spiracle located ventrolaterally. Vent tube dextral. Dorsal fin originating at tail-body junction, dorsal fin parallel to tail musculature and ventral fin arched. Tail length about $60 \%$ of total length, tail tip acute with flagellum.

Pithecopus Cope, 1866

Species occurring in the region. Pithecopus nordestinus (Caramaschi, 2006) (Figure 10D): Cruz (1982), municipality of Itajibá, state of Bahia, Brazil.

Specimens examined. Pithecopus nordestinus: MUFAL 12457 (n $=16$, stages 30-40), municipality of Junqueiro; MUFAL $12464(\mathrm{n}=$ 16, stages 27-31), municipality of Teotônio Vilela, and MUFAL 12483 ( $\mathrm{n}=15$, stages 30-39), municipality of Igaci; both from the state of Alagoas, Brazil; CHUFPB 28074-79 ( $\mathrm{n}=19$, stage 37$)$, municipality of Macaíba, state of Rio Grande do Norte, Brazil.

Characteristics: Body elliptical-elongated in dorsal view, triangularobtuse in lateral view. Snout rounded in dorsal view, truncate in lateral view. Nostrils circular, closer to tip of snout than to eyes. Eyes lateral. Oral disc anterior, not emarginate. Marginal papillae arranged ventrolaterally, with a wide dorsal gap. LTRF 2(2)/3(1). Spiracle midventral. Vent tube dextral. Dorsal fin originating on body, dorsal fin parallel to longitudinal axis of tail and ventral fin arched. Tail length about $60 \%$ of total length, tail tip acute with flagellum.

\section{Family Pipidae}

Pipa Laurenti, 1768

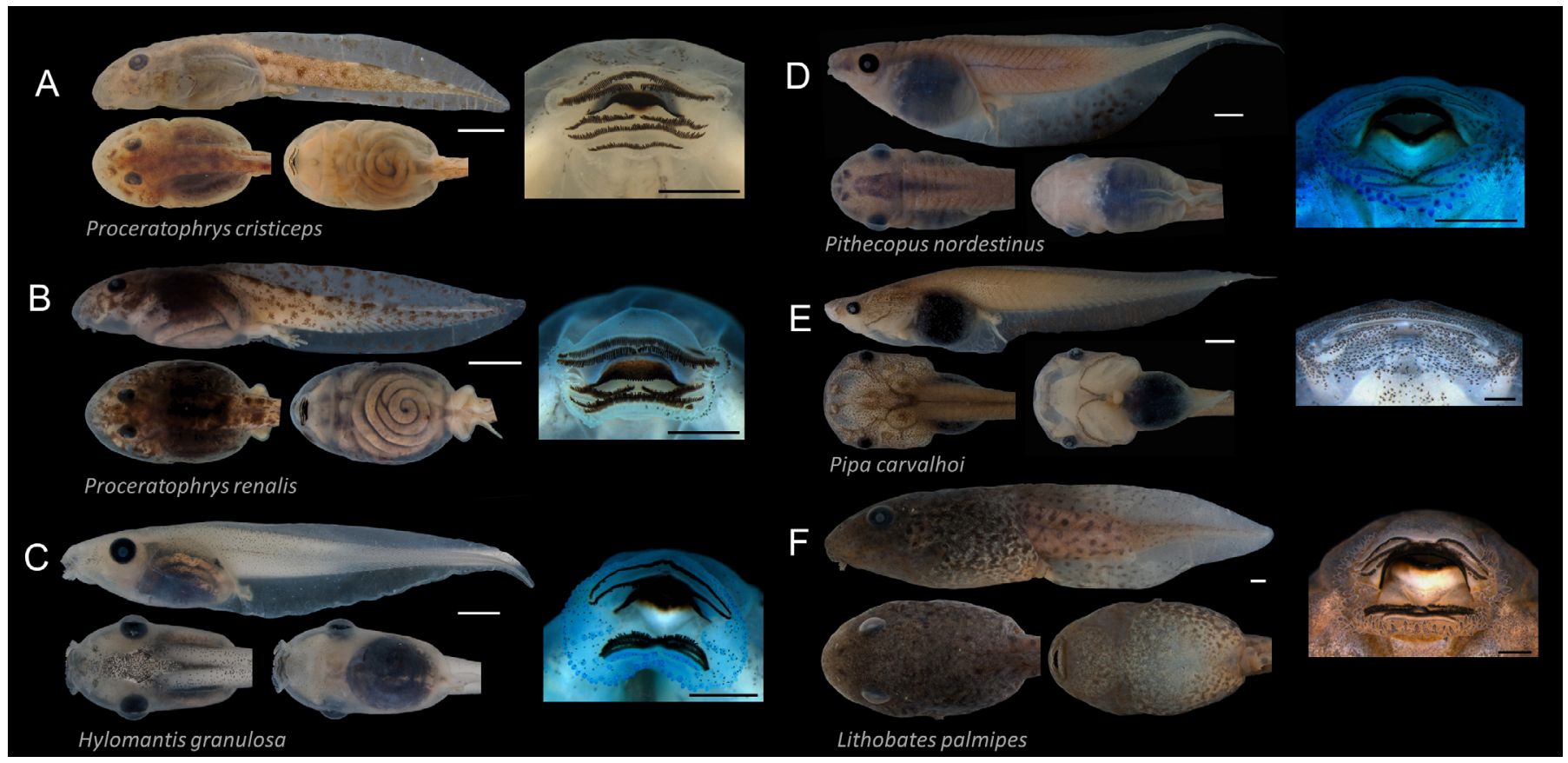

Figure 10. Lateral, dorsal and ventral views $($ scale $=3 \mathrm{~mm})$ and oral disc $(\mathrm{scale}=1 \mathrm{~mm})$ of tadpoles occurring in the north of the Atlantic Forest. 
Species occurring in the region. Pipa carvalhoi (Miranda-Ribeiro, 1937) (Figure 10E): Sokol (1975), municipality of Garanhuns, state of Pernambuco, Brazil.

Specimens examined. Pipa carvalhoi: MUFAL 12485 ( $\mathrm{n}=15$, stages 51-58), municipality of Igaci, state of Alagoas, Brazil; MZFS $379(n=15$, stages 53-58), municipality of Ibicuí, state of Bahia, Brazil.

Characteristics: Body rounded in dorsal view, triangular-obtuse in lateral view. Snout rounded in dorsal view, truncate in lateral view. Nostrils elliptical, closer to tip of snout than to eyes. Eyes lateral. Oral disc anterior, lacking keratinized structures. Marginal papillae absent. Two ventral spiracles. Vent tube medial. Dorsal fin originating on tail, dorsal fin parallel to longitudinal axis of tail and ventral fin arched. Tail length approximately $65 \%$ of total length, tail tip acute with flagellum.

\section{Family Ranidae}

Lithobates Fitzinger, 1843

Species occurring in the region. Lithobates palmipes (Spix, 1824) (Figure 10F): Breder (1946), Panama; Kenny (1968), Trinidad; Radade-Martínez (1990), Venezuela.
Specimens examined. Lithobates palmipes: MUFAL 10183, 1880$81(\mathrm{n}=3$, stage $36-40)$, municipality of Flexeiras, state of Alagoas, Brazil; CHUFPB 28537-40, CHUFPB $28546(n=20$, stages 25-34), municipality of João Pessoa, state of Paraíba, Brazil; CHUFPB 28081 (n $=3$, stage 37), municipality of Areia, state of Paraíba, Brazil; CHUFPB 22887 ( $n=4$, stages 33-35), municipality of Macaíba, state of Rio Grande do Norte, Brazil.

Characteristics: Body elliptical in dorsal view, slightly globulardepressed in lateral view. Snout oval in dorsal and lateral views. Nostrils circular, closer to tip of snout than to eyes. Eyes dorsal. Oral disc anteroventral, emarginate laterally. Marginal papillae arranged ventrolaterally, with a wide dorsal gap. LTRF $4(2,4) / 4(1)$ or 3(2,3)/4(1). Spiracle sinistral. Vent tube dextral, attached to ventral fin. Dorsal fin originating at tail-body junction, dorsal and ventral fins arched. Tail length $60 \%$ of total length, tail tip acute.

Key to tadpoles found in the northern Atlantic Forest (Portuguese version available in Supplementary Material 2)

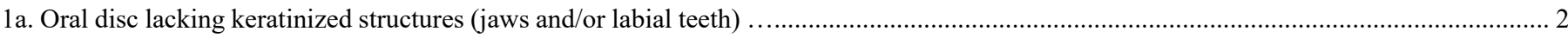

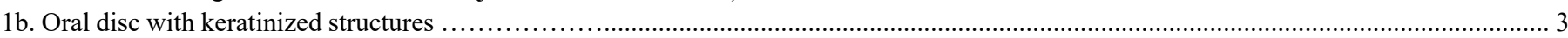

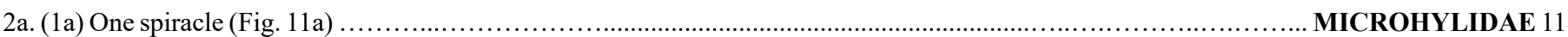

2b. Two spiracles (Fig. 11b)

PIPIDAE: Pipa carvalhoi (Fig. 10e)

3a. (1b) Eyes positioned laterally (Fig. 11e)

3b. Eyes positioned dorsally (Fig. 11f)

4a. (3a) Spiracle ventral (Fig. 11c)

PHYLLOMEDUSIDAE 14

4b. Spiracle sinistral (Fig. 11d)

HYLIDAE 15

5a. (3b) Upper jaw sheath with a medial reentrance (Fig. 11n[i]) ..................... AROMOBATIDAE: Allobates olfersioides (Fig. 3a)

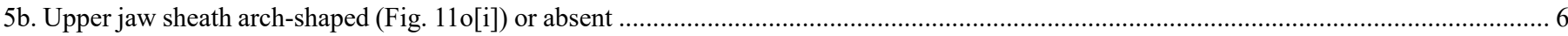

6a. (5b) Oral disc laterally emarginate (Fig. 11n[ii]) or modified in a single dermal fold on anterior lip (Fig. 11ab) …................................. 7

6b. Oral disc not laterally emarginate or modified in two dermal fold on anterior lip (Fig. 11k) ......................................................... 10

7a. (6a) Three or four anterior labial teeth rows

RANIDAE: Lithobates palmipes (Fig. 10f)

7b. Less than three anterior labial teeth rows or anterior labial teeth rows absent .................................................................................... 8

8a. (7b) Marginal papillae on posterior lip with a single and broad medial interruption (Fig. 11v) or marginal papillae completely absent (Fig. 11ab) ....

BUFONIDAE 54

8b. Marginal papillae on posterior lip with two to three interruptions or without interruption

9a. (8b) Marginal papillae on posterior lip without interruption, vent tube dextral (Fig. 11ag) .....

9 b. Only one or none of the characteristics above....

ODONTOPHRYNIDAE 58

10a. (6b) Oral disc not emarginated, anterior margin of oral disc totally fused with body wall ......

LEPTODACTYLIDAE 44

10b. Only one or none of the characteristics above.

LEPTODACTYLIDAE: Leptodactylus 48

11b. Anterior labial flaps do not extend beyond the posterior lip margin (Fig. 11q), dorsal fin originating at body (Fig. 11h)

HYLIDAE 31

12a. (11a) Labial flaps semicircular shaped (Fig. 11s)

Chiasmocleis alagoana (Fig. 9c)

Elachistocleis cesarii (Fig. 9e)

12b. Labial flaps square shaped (Fig. 11r)

13a. (12b) Anterior portion of tail musculature thick with opaque fins (Fig. 9d), tail tip acute without flagellum

Dermatonotus mulleri (Fig. 9d)

13b. Anterior portion of tail musculature thin without opaque fins (Fig. 9f), tail tip acute with flagellum

14a. (4a) Posterior lip visible in dorsal view (Fig. 11g)

14b. Posterior lip not visible in dorsal view

15a. (4b) Three or less labial teeth rows on oral disc

$15 \mathrm{~b}$. More than three labial teeth rows on oral disc

16a. (15a) Maximum ventral fin higher than tail musculature height, body triangular in lateral view (Fig. 2e) ....... Dendropsophus minutus (Fig. 5g)

16b. Maximum ventral fin height equal or less to tail musculature height, body triangular-depressed in lateral view (Fig. 2f) ...................17 
17a. (16b) Row of marginal papillae present (Fig. 11u[i]).

17b. Row of marginal papillae absent (Fig. 11t)

Dendropsophus gr. microcephalus 21

18a. (17a) Row of marginal papillae with two gaps on posterior lip (Fig. 11u[ii]).

.19

18b. Marginal papillae row without gaps on posterior lip.

Dendropsophus gr. decipiens 20

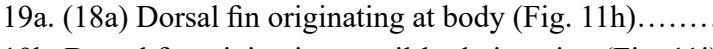

Dendropsophus soaresi (Fig. 5c)

19b. Dorsal fin originating at tail-body junction (Fig. 11i)......

Dendropsophus elegans (Fig. 5b)

20a. (18b) Tail with homogeneous coloration or with small sparse spots near the fins edge, presence of a black bar at mid body (Fig. 4h)........

20b. Tail with large black cross-shaped bars or completely pigmented, black cross-shaped bars absent on body (Fig. 5a)

Dendropsophus haddadi (Fig. 4h)

Dendropsophus oliveirai (Fig. 5a)

21a. (17b) Dorsal fin originating in the middle of the body (Fig. 11h), body length corresponding to $1 / 5$ of total length

Dendropsophus branneri (Fig. 5d)

21b. Dorsal fin originating at posterior body region or at tail-body junction (Fig. 11i), body length corresponding to $1 / 4$ of total length ...........

22a. (21b) Tail musculature width corresponding to half of body width, nostrils elliptical (Fig. 11af)

22b. Tail musculature width corresponding to $60 \%$ of body width, nostrils rounded (Fig. 11ae)

23a. (15b) More than six labial teeth rows on oral disc

23 b. Less than six labial teeth rows on oral disc.

24a. (23b) Presence of long marginal papillae interspersed by conical shorter ones (Fig. 11w), body ovoid in dorsal view (Fig. 2c), vent tube medial (Fig. 11ah).....

24b. Marginal papillae with similar size and shape, body elliptical or elliptical-elongated in dorsal view (Figs. 2a or 2b), vent tube dextral (Fig 11 ag)
Dendropsophus nanus (Fig. 5e)

Dendropsophus studerae (Fig. 5f)

Trachycephalus mesophaeus (Fig. 7e)

Scinax 25

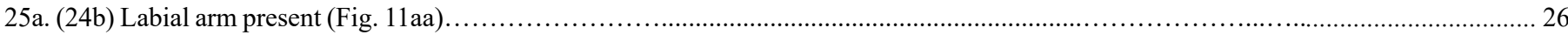

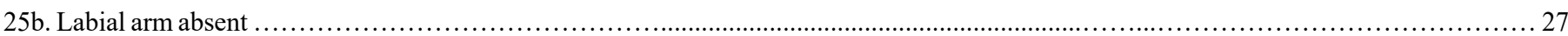

26a. (25a) Wide labial arm with more than 15 labial teeth.

Scinax auratus (Fig. 6e)

26b. Narrow labial arm with less than 10 labial teeth

Scinax nebulosus (Fig. 6f)

27a. (25b) Maximum body height corresponding to half of body length, snout rounded or oval in lateral view

27b. Maximum body height corresponding to $2 / 3$ of body length, snout truncate or sloped in lateral view

...28

28a. (27a) Jaw sheaths narrow, submarginal papillae absent

..29

28b. Jaw sheaths wide, submarginal papillae present (Fig. 11o[ii])

Scinax fuscomarginatus (Fig. 7a)

Scinax pachycrus (Fig. 7b)

29a. (27b) Maximum body height in the region of the spiracle aperture, ventral fin originating at posterior body region, shortly before vent tube insertion (Fig. 111)

29b. Maximum body height in the region of vent tube insertion, ventral fin originating at midbody (Fig. 11m)

Scinax x-signatus (Fig. 7c)

30a. (29a) Spiracle aperture directed posterodorsally, nostrils elliptical (Fig. 11ae), located closer to eyes than to snout, submarginal papillae of unequal size

Scinax fuscovarius (Fig. 6h)

30b. Spiracle aperture directed posteriorly, nostrils rounded (Fig. 11af), located closer to snout than to eyes, submarginal papillae of equal size

Scinax eurydice (Fig. 6g)

31a.(10b) Dorsal fin originating on tail (Fig. 11j).....

Aplastodiscus sibilatus (Fig. 3g)

31b. Dorsal fin originating at body or tail-body junction (Figs. 11h or 11i)

32a. (31b) Ten or more labial teeth rows on oral disc

Corythomantis greeningi (Fig. 4g)

$32 \mathrm{~b}$. Less than ten labial teeth rows on oral disc

Boana 34

33a. (32b) Nostrils reniform (Figs. 11ac or 11ad)

Boana 34

33b. Nostrils rounded or elliptic (Figs. 11ad or 11ae)

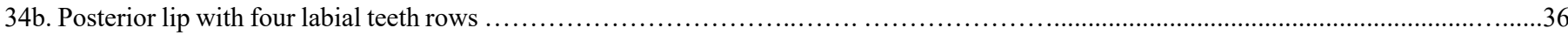

35a. (34a) Body ovoid in dorsal view (Fig. 2c), presence of dark points distributed throughout the body, maximum dorsal fin twice higher than ventral fin height, spiracle three times longer than wide with centripetal wall completely free

Boana raniceps (Fig. 3h)

35b. Body elliptical in dorsal view (Fig. 2a), absence of points on body, dorsal and ventral fins of the same height, spiracle wider than long with just the final portion of the centripetal wall free

Boana atlantica (Fig. 4e)

36a. (34b) Body black or dark gray in ventral view (Fig. 4f), ventral fin arc shaped

Boana semilineata (Fig. 4f)

36b. Body cream or white in ventral view (Figs. 4a-4c), ventral fin parallel to caudal musculature

. .37

37a. (36b) Body elliptic-elongated in dorsal view (Fig. 2b), oral disc ventral, dorsal fin originating in the last third of the body (Fig. 11h)............

Boana freicanecae (Fig. 4d)

37b. Body ovoid or elliptical in dorsal view (Fig. 2a or 2c), oral disc anteroventral, dorsal fin originating at tail-body junction (Fig. 11i)

Boana gr. faber 38 
38a. (37b) Absence of longitudinal strip pigmented in tail musculature and, in early stages, last third of tail dark brown (Fig. 4c) .....

Boana faber (Fig. 4c) 38b. Presence of longitudinal discontinued strip pigmented in the dorsal portion of the tail musculature (brown in life and cream in preservative), last third of tail with homogeneous coloration (Figs. 4a or $4 \mathrm{~b}$ )

39a. (38b) Fourth posterior row of labial teeth short, with length less than $3 / 4$ of the length of third posterior row, absence of unpigmented circular spots on tail musculature.

Boana albomarginata (Fig. 4a)

$39 \mathrm{~b}$. Fourth posterior row of labial teeth very short, with length less than $1 / 4$ of the length of third posterior row, presence of unpigmented circular spots on tail musculature

Boana crepitans (Fig. 4b)

40a. (33b) Three posterior labial teeth rows, posterior lip concave when closed (Fig. 11z)

Ololygon 41

40b. More than three posterior labial teeth rows, posterior lip not concave when closed

Phyllodytes 42

41a. (40a) Nostrils dorsal, located closer to eyes than to snout, second anterior labial teeth row without medial gap, tail with homogeneous light coloration (Fig. 6a)

.ololygon skuki (Fig. 6a)

41b. Nostrils dorsolaterally, located closer to snout than to eyes, second anterior labial teeth row with medial gap, tail with large dark brown bar in the end portion (Fig. $5 \mathrm{~h})$.......

Ololygon melanodactyla (Fig. 5h)

42a. (40b). Oral disc ventrally modified in two cloven lobes on anterior lip, a small semicircular posterior lip, an abdominal sucker covering the first half of the body (Fig. 11k) .

Phyllodytes gyrinaethes (Fig. 6d)

42b. Oral disc unmodified

.Phyllodytes gr. luteolus 43

43a. (42b) Body elliptical in dorsal view (Fig. 2a), dorsal fin originating in the last third of the body (Fig. 11h), five or more labial teeth rows on the posterior lip ....

Phyllodytes brevirostris or Phyllodytes edelmoi (Fig. 6c)

43b. Body ovoid in dorsal view (Fig. 2c), dorsal fin originating at tail-body junction (Fig. 11i), four labial teeth rows on the posterior lip...........

Phyllodytes acuminatus (Fig. 6b)

44a. (9b) Third posterior row of labial teeth short, with length less than half of the length of second posterior row .45

$44 \mathrm{~b}$. Posterior labial teeth rows equal in length.

45a. (44a) Marginal papillae row with three gaps on the posterior lip (Fig. 11x)

45b. Marginal papillae row without gaps on the posterior lip.

46a. (44b) Marginal papillae row with two gaps on the posterior lip (Fig. 11y).....

Physalaemus albifrons (Fig. 8f) or Physalaemus cuvieri (Fig. 8g) Pseudopaludicola 47

46b. Marginal papillae row without gaps on the posterior lip.. Physalaemus caete 47a. (46a) Presence of dark spots on fins (Fig. 9a), body elliptical in dorsal view (Fig. 2a) ......................Pseudopaludicola mystacalis (Fig. 9a) 47b. Absence of dark spots on fins (Fig. 9b), body ovoid in dorsal view (Fig. 2c) .............................Pseudopaludicola pocoto (Fig. 9b)

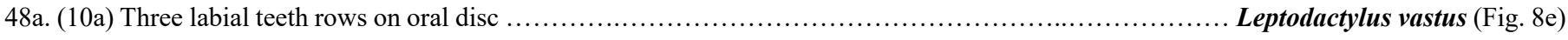

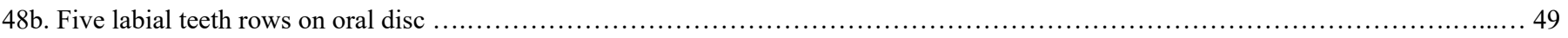
49a. (48b) Second anterior labial teeth row with medial gap, a simple row of marginal papillae in the posterior lip..............Leptodactylus gr. fuscus 50 49b. Second anterior labial teeth row without medial gap, two or three rows of marginal papillae in the posterior lip ................................53 50a. (49a) Dorsal portion of tail musculature fully pigmented (brown in life and cream in preservative, Fig. 7g), lower jaw sheath U-shaped (Fig. 11o[iii]) Leptodactylus caatingae (Fig. $7 \mathrm{~g}$ ) 50b. Tail musculature with unpigmented homogeneous coloring or with sparse dark stains (Figs. 7h-8b), lower jaw sheath V-shaped (Fig. 11n[iii])

51a. (50b) Maximum body width on the half or on the last third of the body, second anterior labial teeth short, with a medial gap corresponding to about 13 labial teeth and, from stage 36, presence of three or more dark brown transverse bars on dorsum ....

.Leptodactylus troglodytes (Fig. 8b) 51b. Maximum body width just behind the eyes, second anterior labial teeth with a medial gap corresponding to about 30 labial teeth, without pigmentation on body ...52 52a. (51b) Interorbital distance less than $40 \%$ of body width, spiracle twice longer than wide with centripetal wall completely fused to wall of the body Leptodactylus mystaceus (Fig. 8a) $52 \mathrm{~b}$. Interorbital distance greater than $40 \%$ of body width, spiracle about the same width and length with the final portion of the centripetal wall free.

Leptodactylus fuscus (Fig. 7h) 53a. (49b) Oral disc with a pair of ventral folds when closed, eye diameter larger than the distance from nostrils to the snout

Leptodactylus natalensis (Fig. 8d) 53b. Oral disc without ventral folds, eye diameter with half the distance from nostrils to the snout Leptodactylus macrosternum (Fig. 8c)

54a. (8a) Presence of marginal papillae Rhinella 55

54b. Marginal papillae completely absent (Fig. 11ab)......

Frostius pernambucensis (Fig. 3b)

55a. (54a) Third posterior row of labial teeth short, with length less than half of the length of second posterior row ........Rhinella granulosa (Fig. 3d)

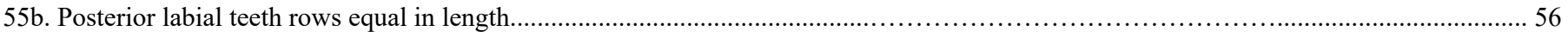
56a. (55b) Body with light coloration in dorsal view, ranging from cream to dark cream (Fig. 3e), weakly pigmented tail musculature, with homogeneous color (Fig. 3e). Rhinella hoogmoedi (Fig. 3e) 
56b. Body with dark coloration in dorsal view, ranging from dark brown to black (Figs. 3c or 3f), tail musculature strongly pigmented, longitudinal strip unpigmented in the ventral portion of the tail musculature (Figs. $3 \mathrm{c}$ or $3 \mathrm{f}$ ).

. .57

57a. (56b) Body elliptical in dorsal view (Fig. 2a), eye diameter equal or larger than the distance from nostrils to the snout, first third of dorsal fin with concave contour

Rhinella crucifer (Fig. 3c) 57b. Body ovoid in dorsal view (Fig. 2c), eye diameter with half the distance from nostrils to the snout, first third of dorsal fin with arched contour

Rhinella jimi (Fig. 3f)

58a. (9a) Body rounded in lateral view (Fig. 2d), anterior margin of oral disc totally fused with body wall, tail short, representing approximately $50 \%$ of total length

Macrogenioglottus alipioi (Fig. 9g)

58 b. Body globular/depressed in lateral view (Fig. 2i), anterior margin of oral disc free, tail representing more than $60 \%$ of total length ........ 59

59a. (58b) Second anterior labial teeth row with medial gap, body ovoid in dorsal view (Fig. 2c) ....

Proceratophrys 60

59b. Second anterior labial teeth row without medial gap, body elliptical in dorsal view (Fig. 2a)

Odontophrynus carvalhoi (Fig. 9h)

60a. (59a) Body dark brown in dorsal view (Fig. 10b), nostrils reniform (Figs. 11ac or 11ad), centripetal wall of spiracle free from body

Proceratophrys renalis (Fig. 10b)

60b. Body light brown in dorsal view (Fig. 10a), nostrils rounded (Fig. 11ae), centripetal wall of spiracle fused to body

Proceratophrys cristiceps (Fig. 10a)

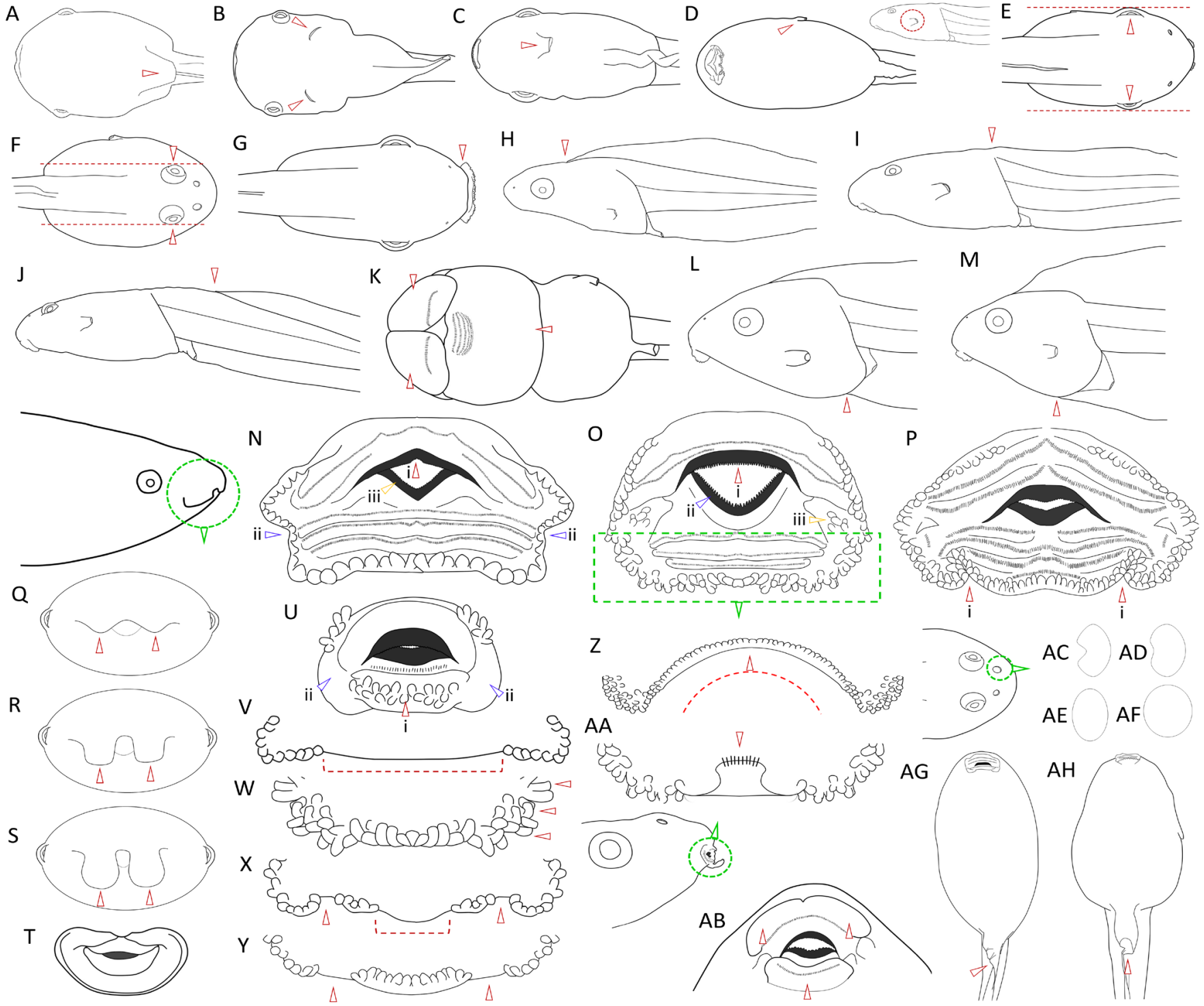

Figure 11. Morphological characteristics used to larval characterizations and in the taxonomic key. Details of characteristics are mentioned in the taxonomic key. 


\section{Discussion}

The great morphological diversity of tadpoles is related to the large number of species, genera and families of anurans occurring in the Atlantic Forest north of the São Francisco River, as well as to the diversity of habitats and habits of their tadpoles. The tadpoles of the 63 species from the northern region of the Atlantic Forest with known larval phase represent almost all guilds (sensu Altig \& McDiarmid 1999; Rossa-Feres et al. 2004) with diverse feeding habits such as suctorials, raspers, carnivorous, macrophages and endotrophics (Dubeux et al. 2019). Most tadpoles develop in lentic or lotic environments, but five in phytotelmata (Frostius pernambucensis and Phyllodytes spp.), one in association with rocky streams (Corythomantis greeningi) and one probably has endotrophic tadpoles that complete development in a foam nest placed in an underground burrow (Adenomera aff. hylaedactyla). Unfortunately, the feeding habit and microhabitat use for several tadpoles remain unknown (Dubeux et al. 2019).

Tadpole identification remains an enormous challenge in the Neotropics mostly due to the difficulty in recognizing and distinguishing morphological characteristics. Dichotomous keys are important tools for identifying organisms. Although the first identification keys for tadpoles were published more than a century ago (Boulenger 1892, Altig 1970, Lips \& Savage 1996, Mijares-Urrutia 1998), they included few characteristics and few illustrations without enough details. Currently, a dozen or so identification keys are available for tadpoles, most of them for small groups of species (Haas et al. 2009, see below) or restricted regions (e.g., Hero 1990, Rossa-Feres \& Nomura 2006).

The first tadpole key for Brazilian species was developed by Hero (1990) and included 36 species that occur in the municipality of Manaus, state of Amazonas. Despite this beginning, most taxonomic keys available for tadpoles in Brazil are concentrated in the South and Southeastern regions. Rossa-Feres \& Nomura (2006) included 22 species in a key for tadpoles of northwest region of São Paulo state. A year later, Machado \& Maltchink (2007) published a key included 44 taxa (species and genera) of the state of Rio Grande do Sul. A tadpole key published in a book included 49 species obtained in the municipalities of Conceição do Mato Dentro, Alvorada de Minas and Dom Joaquim, all in state of Minas Gerais (Pimenta et al. 2014). Four years later, an identification key for 11 species from Ilha Grande, state of Rio de Janeiro, was published (Fatorelli et al. 2017). Recently, an interactive identification key was made available online, including 66 species from a region designated Quadrilátero Ferrifero, in the state of Minas Gerais (Pezzuti et al. 2019). Herein, we provide an key for tadpoles in the northern region of the Atlantic Forest, the first for Northeastern Brazil, contributing to fill one of the knowledge gaps identified during the "Tadpoles International Workshop" (Rossa-Feres et al. 2015): "How can we improved taxonomic identification of larval stages?". We expect this key and the morphological characterization of tadpoles presented here will stimulate further studies with Brazilian larval anurans.

\section{Supplementary Material}

The following online material is available for this article:

Supplementary Material 1 - List of anuran amphibians recorded in the northern region of the Atlantic Forest.

Supplementary Material 2 - Chave de identificação para os girinos encontrados no norte da Mata Atlântica.

\section{Acknowledgements}

The authors thank M. Napoli (UFBA), S. Torquato (MUFAL), V. Orrico (MZUESC), F. Juncá (MZFS), F. Delfim (CHUFPB), P. Nunes and P. Simões (CHUFPE), and M. Kokubum (LHUFCG) for allowing us to study specimens under their care; K. Picheli (UNIFEV), M. Kokubum (UFCG), R. Abreu (UFBA), and R. Costa and C. Mira-Mendes (UESC) for photographs; L. Weber (UFSB) for his help in obtaining material analyzed; G. Rodrigues (U.PORTO), I. Santos, B. Lisboa (UFPE), A. Valencia-Aguilar (UNESP), B. Vilela (UFBA), G. Ruano-Fajardo and G. Skuk (in memoriam) for their helping in advancing the state of knowledge of tadpoles in the state of Alagoas. We thank all those who volunteered to test the identification key presented here and certainly contributed to this study. We also thank the editor M. Napoli (UFBA) and the two reviewers for the valuable suggestions that contributed to the improvement of this work. DCRF and TM are grateful to the project "Tadpoles from Brazil" (Edital SISBIOTA, Process CNPq 563075/20104 and FAPESP 2010/52321-7). MJMD thanks Fundação de Amparo a Ciência e Tecnologia do Estado de Pernambuco - FACEPE (IBPG1117-2.04/19) for financial support. DCRF thanks Conselho Nacional de Desenvolvimento Científico e Tecnológico - CNPq for the research fellowship (302328/2017-3). TM thanks CNPq (309904/2015-3) for financial support. This study was financed in part by the Coordenação de Aperfeiçoamento de Pessoal de Nível Superior - Brasil (CAPES) 88882.440382/2019-01.

\section{Author Contributions}

Marcos Jorge Matias Dubeux: Contribution to the conception and design of the work, data acquisition, data analysis and interpretation; writing and critical review of the manuscript, adding intellectual content.

Filipe Augusto Cavalcanti do Nascimento: Contribution to the conception and design of the work, data analysis and interpretation; writing and critical review of the manuscript, adding intellectual content.

Luana Rodrigues Lima: Contribution to the conception and design of the work, data acquisition, data analysis and interpretation; writing and critical review of the manuscript, adding intellectual content.

Felipe de Medeiros Magalhães: Contribution to the conception and design of the work, data analysis and interpretation; writing and critical review of the manuscript, adding intellectual content.

Izabel Regina Soares da Silva: Contribution to the conception and design of the work, data analysis and interpretation; writing and critical review of the manuscript, adding intellectual content.

Ubiratan Gonçalves: Contribution to the writing and critical review of the manuscript, adding intellectual content.

João Paulo Felix Almeida: Contribution to the writing and critical review of the manuscript, adding intellectual content.

Larissa Lima Correia: Contribution to the writing and critical review of the manuscript, adding intellectual content.

Adrian Antonio Garda: Contribution to the writing and critical review of the manuscript, adding intellectual content.

Daniel Oliveira Mesquita: Contribution to the writing and critical review of the manuscript, adding intellectual content.

Denise de Cerqueira Rossa-Feres: Contribution to the conception and design of the work, data analysis and interpretation; writing and critical review of the manuscript, adding intellectual content. 
Tamí Mott: Contribution to the conception and design of the work, data analysis and interpretation; writing and critical review of the manuscript, adding intellectual content.

\section{Conflicts of Interest}

The author(s) declare(s) that they have no conflict of interest related to the publication of this manuscript.

\section{References}

ABRAVAYA, J.P. \& JACKSON, J.F. 1978. Reproduction in Macrogenioglottus alipioi Carvalho (Anura, Leptodactylidae). Nat. Hist. Mus. Los. Ang. Cty. Contrib. Sci. 298:1-9.

ABREU, R.O., JUNCÁ, F.A., SOUZA, I.C.A. \& NAPOLI, M.F. 2015. The tadpole of Dendropsophus branneri (Cochran, 1948) (Amphibia, Anura, Hylidae). Zootaxa 3946(2):296-300.

ABREU, R.O., NAPOLI, M.F., CAMARDELLI, M. \& FONSECA, P.M. 2013. The tadpole of Dendropsophus haddadi (Amphibia, Anura, Hylidae): additions on morphological traits and comparisons with tadpoles of the $D$. decipiens and D. microcephalus species groups. Sitientibus Série Ciências Biológicas 13:1-4.

ABREU, R.O., NAPOLI, M.F., TREVISAN, C.C., CAMARDELLI, M., DÓRIA, T.A.F. \& SILVA, L.M. 2015. The tadpole of Scinax melanodactylus (Lourenço, Luna \& Pombal Jr, 2014) (Amphibia, Anura, Hylidae). Zootaxa 3981(3):430-436.

ALMEIDA, J.P.F.A., NASCIMENTO, F.A.C., TORQUATO, S., LISBOA, B.S., TIBÚRCIO, I.C.S., PALMEIRA, C.N.S., LIMA, M.G. \& MOTT, T. 2016. Amphibians of Alagoas State, northeastern Brazil. Herpetol. Notes 9:123-140.

ALTIG, R. \& MCDIARMID, R. W. 1999. Body plan: Development and morphology. In Tadpoles: The Biology of Anuran Larvae (R.W. McDiarmid $\&$ R. Altig, eds). University of Chicago Press, Chicago, p.24-50.

ALTIG, R. 1970. A key to the tadpoles of the continental United States and Canada. Herpetologica 26(2):180-207.

ALVES, A.C.R., GOMES, R. \& CARVALHO, S.P. 2004. Description of the tadpole of Scinax auratus (Wied-Neuwied) (Anura, Hylidae). Rev. Bras. Zool. 21(2):315-317.

AMPHIBIAWEB. 2020. https://amphibiaweb.org . University of California, Berkeley, CA, USA (last access in 09/Apr/2020).

ANDRADE, G.V., ETEROVICK, P.C., ROSSA-FERES, D.C. \& SCHIESARI, L. 2007. Estudos sobre girinos no Brasil: histórico, situação atual e perspectivas. In Herpetologia no Brasil II (L.B. Nascimento \& M.E. Oliveira, orgs). Soc. Bras. Herpetol., Belo Horizonte, p.127-145.

ASSIS, J.S. 2000. Biogeografia e conservação da biodiversidade - projeções para Alagoas. Edições Catavento, Maceió.

BARBOSA, V.N., PEREIRA, E.N., \& MARANHÃO, E.S. 2017. Anfíbios da Estação Ecológica de Caetés Paulista, Pernambuco - Atualização da lista de espécies. Rev. Ciên. Amb. 11(2):39-49.

BOKERMANN, W.C.A. 1962. Observações biológicas sôbre "Physalaemus cuvieri" Fitz., 1826 (Amphibia, Salientia). Rev. Bras. Biol. 22(4):391-399.

BOKERMANN, C.A. 1963. Girinos de anfíbios brasileiros - I (Amphibia Salientia). An. Acad. Bras. Ciênc. 35(3):465-474.

BOKERMANN, W.C.A. 1973. Duas novas espécies de Sphaenorhynchus da Bahia (Anura, Hylidae). Rev. Bras. Biol. 33(4):589-594.

BOULENGER, G.A. 1892. Description of new reptiles and batrachians from the Loo Choo islands. Ann. Mag. Nat. Hist. 13(18):302-304.

BREDER, J.C.M. 1946. Amphibians and reptiles of the rio Chucunaque drainage, Darien, Panama, with notes on their life histories and habits. Bull. Am. Museum Nat. Hist. 86(8):375-436.

CAMPOS, T.F., LIMA, M.G., NASCIMENTO, F.A.C. \& SANTOS, E.M. 2014. Larval morphology and advertisement call of Phyllodytes acuminatus Bokermann, 1966 (Anura: Hylidae) from Northeastern Brazil. Zootaxa 3779(1):93-100.
CARAMASCHI, U. 1979. O girino de Odontophrynus carvalhoi Savage \& Cei, 1965 (Amphibia, Anura, Ceratophrydidae). Rev. Bras. Biol. 39(1):169-171.

CARNAVAL, C.A.O.Q. \& PEIXOTO, O.L. 2004. A new species of Hyla from northeastern Brazil (Amphibia, Anura, Hylidae). Herpetologica 60(3):387-395.

CARNEIRO, M.C.L., MAGALHÃES, P.S. \& JUNCÁ, F.A. 2004. Descrição do girino e vocalização de Scinax pachycrus (Miranda-Ribeiro, 1937) (Amphibia, Anura, Hylidae). Arq. do Mus. Nac. 62(3):241-246.

CARVALHO-E-SILVA, S.P., CARVALHO-E-SILVA, A.M.P.T. \& IZECKSOHN, E. 2003. Nova espécie de Hyla laurenti do grupo de H. microcephala Cope (Amphibia, Anura, Hylidae) do nordeste do Brasil. Rev. Bras. Zool. 20(3):553-558.

CARVALHO-E-SILVA, S.P., CORREA PINTO, A.L. \& CARVALHO-ESILVA, A.M.P.T. 2002. Aspectos da reprodução, da vocalização e da larva Phrynohyas mesophaea (Amphibia, Anura, Hylidae). Rev. Aquarium 15:19-24.

CASAL, F.C. \& JUNCÁ, F.A. 2008. Girino e canto de anúncio de Hypsiboas crepitans (Amphibia: Anura: Hylidae) do estado da Bahia, Brasil, e considerações taxonômicas. Bol. do Mus. Para. Emilio Goeldi 3(3):217-224.

CASCON, P. \& PEIXOTO, O.L. 1985. Observações sobre a larva de Leptodactylus troglodytes A. Lutz, 1926 (Amphibia, Anura, Leptodactylidae). Rev. Bras. Biol. 45:361-364.

CEI, J. M. 1980. Amphibians of Argentina. Monit. Zool. Ital., N.S., Monografia.

COSTA, E.F., NASCIMENTO, F.A.C., JÚNIOR, M. M. \& SANTOS, E.M. 2017. Aspectos de vida de Odontophrynus carvalhoi Savage \& Cei, 1965 (Amphibia, Anura, Odontophrynidae) em um brejo de altitude no Nordeste brasileiro. Bol. Mus. Biol. Mello Leitão 39(2):95-115.

CRUZ, C.A.G. 1982. Conceituação de grupos de espécie de Phyllomedusinae brasileiras com base em caracteres larvários (Amphibia, Anura, Hylidae) Arq. Univ. Fed. Rur. Rio de J. 5(2):147-171.

CRUZ, C.A.G. \& PEIXOTO, O.L. 1982. Sobre a biologia de Atelopus pernambucencis Bokermann, 1962 (Amphibia, Anura, Bufonidae). Rev Bras. Biol. 42(3):627-629.

CRUZ, C.A.G., NUNES, I., \& JUNCÁ, F.A. 2012. Redescription of Proceratophrys cristiceps (Müller, 1883) (Amphibia, Anura, Odontophrynidae), with description of two new species without eyelid appendages from northeastern Brazil. S. Am. J. Herpetol. 7: 110-122.

DE SÁ, R.O., GRANT, T., CAMARGO, A., HEYER, W.R., PONSSA, M.L. \& STANLEY, E. 2014. Systematics of the neotropical genus Leptodactylus Fitzinger, 1826 (Anura: Leptodactylidae): phylogeny, the relevance of non-molecular evidence, and species accounts. S. Am. J. Herpetol. 9(s1): S1-S128.

DIXON, JR. \& STATON, M.A. 1976. Some aspects of the biology of Leptodactylus macrosternum Miranda-Ribeiro (Anura: Leptodactylidae) of the Venezuelan Llanos. Herpetologica 322:227-232.

DUBEUX, M.J.M., DA-SILVA, G.R.S., NASCIMENTO, F.A.C., GONÇALVES, U., \& MOTT, T. 2019. Síntese histórica e avanços no conhecimento de girinos (Amphibia: Anura) no estado de Alagoas, nordeste do Brasil. Rev. Nordest. Zool. 12(1):18-52.

DUBEUX, M.J.M., SILVA, T., MOTT, T \& NASCIMENTO, F.A.C. 2020a. Redescription of the tadpole of Leptodactylus natalensis Lutz (Anura: Leptodactylidae), an inhabitant of the Brazilian Atlantic Forest. Zootaxa 4732:346-350.

DUBEUX, M.J.M., GONÇALVES, U., NASCIMENTO, F.A.C. \& MOTT, T. 2020b. Anuran amphibians of a protected area in the Northern Atlantic Forest with comments on topotypic and endangered populations. Herpetol. Notes 13:61-74.

DUELLMAN, W.E. 1978. The biology of an equatorial herpetofauna in Amazonian Ecuador. Misc. Publ. Mus. Nat. Hist. Univ. Kansas 65:1-352.

DUELLMAN, W.E. \& TRUEB, T. 1994. Biology of Amphibia. $2^{\mathrm{a}}$ ed. The Johns Hopkins University Press, Baltimore.

DUELLMAN, W.E. \& TRUEB, L. 2015. Marsupial frogs, Gastrotheca and allied genera. Johns Hopkins University Press, Baltimore.

FABREZI, M. \& VERA, R. 1997. Caracterización morfológica de larvas de anuros del Noroeste Argentino. Cuad. Herpetol. 11(1-2):37-49. 
FAIVOVICH, J. 2002. A cladistic analysis of Scinax (Anura: Hylidae). Cladistics 18(4):367-393.

FAIVOVICH, J., HADDAD, C. F., GARCIA, P. C., FROST, D. R., CAMPBELL, J. A., \& WHEELER, W. C. 2005. Systematic review of the frog family Hylidae, with special reference to Hylinae: phylogenetic analysis and taxonomic revision. Bull. Am. Mus. Nat. Hist. 2005(294):1-240.

FATORELli, P., NOGUEIRA-COSTA, P. \& ROCHA, C.F.D. 2017. Characterization of tadpoles of the southward portion (oceanic face) of Ilha Grande, Rio de Janeiro, Brazil, with a proposal for identification key. North-West. J. Zool. 4(2):171-184.

FROST, D.R. 2020. Amphibian species of the world, version 6.0. American Museum of Natural History, New York, USA Online Reference. http:// research.amnh.org/herpetology/amphibia/index.php (last access in 09/ Apr/2020).

GOMES, M.R. \& PEIXOTO, O.L. 1991a. Larvas de Hyla do grupo "leucophyllata" com a descrição de H. elegans Wied, 1824 e notas sobre a variação do pradrão de colorido do adulto nesta espécie (Anura, Hylidae). Rev. Bras. Biol. 51:257-262.

GOMES, M.R. \& PEIXOTO, O.L. 1991b. Considerações sobre os girinos de Hyla senicula (Cope, 1868) e Hyla soaresi (Caramaschi e Jim, 1983) (Amphibia, Anura, Hylidae). Acta Biol. Leopold. 13:5-18.

GOMES, M. R., ALVES, A.C.R. \& PEIXOTO, O.L. 2014. O girino de Scinax nebulosus (Amphibia, Anura, Hylidae). Iheringia. Série Zool. 104(2):184188.

GOSNER, K.L. 1960. A simplified table for staging anuran embryos and larvae with notes on identification. Herpetologica 16(3):183-190.

GROSJEAN, S. 2005. The choice of external morphological characters and developmental stages for tadpole-based anuran taxonomy: a case study in Rana (Sylvirana) nigrovittata (Blyth, 1855)(Amphibia, Anura, Ranidae). Contrib. Zool. 74(1-2):61-76.

HAAS, A., WOLTER, J., HERTWIG, S.T. \& DAS, I. 2009. Larval morphologies of three species of stream toads, genus Ansonia (Amphibia: Bufonidae) from east Malaysia (Borneo), with a key to known Bornean Ansonia tadpoles. Zootaxa 2302(1):21-18.

HEDGES, S.B., DUELLMAN, W.E. \& HEINICKE, M.P. 2008. New World direct-developing frogs (Anura: Terrarana): molecular phylogeny, classification, biogeography, and conservation. Zootaxa 1737(1):1-182.

HERO, J.M.. 1990. An illustrated key to tadpoles occurring in the Central Amazon rainforest, Manaus, Amazonas, Brazil. Amazoniana 11(2):201-262.

HEYER, W.R. 1978. Systematics of the fuscus group of the frog genus Leptodactylus (Amphibia, Leptodactylidae). Sei. Natur. Hist. Mus. Los Angeles County. 29:1-85.

HEYER, W.R., RAND, A.S., CRUZ, C.A.G., PEIXOTO, O.L. \& NELSON, C.E. 1990. Frogs of Boracéia. Arq. Zool. 31(4):231-410.

ICMBIO. 2018. Fauna brasileira ameaçada de extinção. In: Fauna Brasileira Ameaçada de Extinção. Fundação Biodiversitas para a Conservação da Diversidade Biológica. Brasília, Distrito Federal.

IUCN. 2020. The IUCN Red List of Threatened Species. Version 2020-1, International Union for Conservation of Nature and Natural Resources. $\mathrm{http}: / /$ www.iucnredlist.org (last access in 09/Apr/2020).

JUNCÁ, F.A., CARNEIRO, M.C.L. \& RODRIGUES, N.N. 2008. Is a dwarf population of Corythomantis greeningi Boulenger, 1896 (Anura, Hylidae) a new species? Zootaxa 1686 (56):48-56.

KENNY, J.S. 1968. The Amphibia of Trindad. Stu. Fauna Curaçao other Carib. Isl. 29:1-78.

KOKUBUM, M.N.C. \& DE SOUSA, M.B. 2008. Reproductive ecology of Leptodactylus aff hylaedactylus (Anura, Leptodactylidae) from an open area in northern Brazil. S. Am. J. Herpetol. 3:15-21.

KOKUBUM, M.N.C. \& MACIEL, N.M. 2009. Reproductive biology of the Brazilian sibilator frog Leptodactylus troglodytes. Herpetol. J. 19:119-126.

KOLENC, F., BORTEIRO, C., ALCALDE, L., BALDO, D., CARDOZO, D. \& FAIVOVICH, J. 2008. Comparative larval morphology of eight species. Zootaxa 1927(1):1-66.
LANTYER-SILVA, A. S., MATOS, M. A., GOGLIATH, M., MARCIANOJR, E. \& NICOLA, P. A. 2016. New records of Pseudopaludicola pocoto Magalhães, Loebmann, Kokubum, Haddad \& Garda, 2014 (Amphibia: Anura: Leptodactylidae) in the Caatinga Biome, Brazil. CheckList 12(6): $1-4$

LAUFER, G., PEREYRA, L.C., AKMENTINS, M.S., \& BORTEIRO, C. 2013. A comment on the oral dermal flaps of Elachistocleis Parker, 1927 (Anura: Microhylidae) larvae. Zootaxa 3710(5): 498-500.

LAVILLA, E.O. 1990. The tadpole of Hyla nana (Anura: Hylidae). J. Herpetol. 24(2):207-209.

LAVILLA, E.O. 1992. The tadpole of Dermatonotus muelleri (Anura: Microhylidae). Bolletino del Mus. Reg. di Sci. Nat. Torino 10(1):62-71.

LEITE-FILHO, E., DE-OLIVEIRA, F.A., ELOI, F.J., LIBERAL, C.N., LOPES, A.O., \& MESQUITA, D.O. 2017. Evolutionary and ecological factors influencing an anuran community structure in an Atlantic Rainforest urban Fragment. Copeia 105(1):64-74.

LEON, J.R. 1975. Desarrollo temprano y notas sobre la historia natural de la larva de Hyla x-signata (Amphibia: Hylidae). Caribb. J. Sci. (15):57-65.

LESCURE, J. 1972. Contribution a l'étude des amphibians de Guyane Française. II. Leptodactylus fuscus (Schneider) observation écologiques et éthologiques. Ann. Mus. Hist. Nat. Nice 1:91-100.

LIPS, K.R., \& SAVAGE, J. M. 1996. Key to the known tadpoles (Amphibia: Anura) of Costa Rica. Stud. Neotrop. Environ. 31(1):17-26.

LISBOA, B., SANTOS, W. F. S., TORQUATO, S., GUARNIERI, M. C., \& MOTT, T. 2019. A new state record of the glassfrog Vitreorana baliomma (Anura: Centrolenidae), with notes on its reproductive biology. Herpet. Notes 12:957-960.

LISBOA, B.S., NASCIMENTO, F.A.C.D. \& SKUK, G.O. 2011. Redescription of the tadpole of Macrogenioglottus alipioi (Anura: Cycloramphidae), a rare and endemic species of the Brazilian Atlantic Forest. Zootaxa 3046(1):67-68.

LOEBMANN, D., ORRICO, V.G.D. \& HADDAD, C.F.B. 2011. First record of Adelophryne baturitensis Hoogmoed, Borges \& Cascon, 1994 for the state of Pernambuco, northeastern Brazil (Anura, Eleutherodactylidae, Phyzelaphryninae). Herpetol. Notes 4:75-77.

LUTZ, B. 1973. Brazilian species of Hyla. University of Texas Press, Austin.

LYNCH, J.D. 2006. The tadpoles of frogs and toads found in the lowlands of northern Colombia. Rev. la Acad. Colomb. Ciencias Exactas, Fis. y Nat. 30(116):443-457.

MACHADO, I.F. \& MALTCHINK, L. 2007. Check-list da diversidade de anuros no Rio Grande do Sul (Brasil) e proposta de classificação para as formas larvais. Neotrop. Biol. Conserv. 2(2):101-116.

MACIEL, D.B., \& NUNES, I. 2010. A new species of four-eyed frog genus Pleurodema Tschudi, 1838 (Anura: Leiuperidae) from the rock meadows of Espinhaço range, Brazil. Zootaxa 2640:53-61.

MAGALHÃES, F.M., SANTANA, D.J., NETO, A.M., \& GARDA, A.A. 2012. The tadpole of Elachistocleis cesarii Miranda-Ribeiro, 1920 (Anura, Microhylidae). Zootaxa 3187: 54-56.

MAGALHÃES, F.M., GARDA, A. A., AMADO, T. F., \& DE SÁ, R. O. 2013a. The tadpole of Leptodactylus caatingae Heyer \& Juncá, 2003 (Anura: Leptodactylidae): External morphology, internal anatomy, and natural history. S. Am. J. Herpetol. 8(3):203-211.

MAGALHÃES, F.M., DANTAS, A.K.B.P., BRITO, M.R.M., MEDEIROS, P.H.S., OLIVEIRA, A.F., PEREIRA, T.C.S.O, QUEIROZ, M.H.C., SANTANA, D.J., SILVA, W.P. \& GARDA, A.A. 2013b. Anurans from an Atlantic forest-caatinga ecotone in Rio Grande do Norte State, Brazil. Herpetol. Notes 6:1-10.

MAGALHÃES, F.M., LOEBMANN, D., KOKUBUM, M.N.D.C., HADDAD, C.F.B., \& GARDA, A.A. 2014. A new species of Pseudopaludicola (Anura: Leptodactylidae: Leiuperinae) from northeastern Brazil. Herpetologica 70(1):77-88.

MCDIARMID, R. W. \& ALTIG, R. 1999. Introduction: the tadpole arena. In Tadpoles: the biology of anuran larvae (R. W. McDiarmid \& R. Altig, eds). University of Chicago Press, Chicago, p.1-6. 
MENIN, M., ALMEIDA, A.P. \& MARCELO, M.N. 2009. Reproductive aspects of Leptodactytus hylaedactylus (Anura: Leptodactylidae), a member of the Leptodactylus marmoratus species group, with a description of tadpoles and calls. J. Nat. Hist. 43(35-36):2257-2270.

MERCÊS, E.A. \& JUNCÁ, F.A. 2010. Girinos de três espécies de Aplastodiscus Lutz, 1950 (Anura - Hylidae) ocorrentes no Estado da Bahia, Brasil. Biota Neotrop. 10(4):167-172. http://www.biotaneotropica.org.br/v10n4/en/ abstract?article+bn03410042010 (last access on 09/Apr/2020).

MERCÊS, E.A., JUNCÁ, F.A. \& CASAL, F.S.C. 2009. Girinos de três espécies do gênero Rhinella Fitzinger, 1826 (Anura, Bufonidae) ocorrentes no estado da Bahia, Brasil. Sitientibus, série Ciências Biológicas, 9(2-3):133-138.

MESQUITA, D.O., ALVES, B., PEDRO, C., LARANJEIRAS, D., CALDAS, F., PEDROSA, I., RODRIGUES, J.B., DRUMMOND, L.O., CAVALCANTI, L.B.Q., WACHLEVSKI, M., NOGUEIRA-COSTA, P., FRANÇA, R.C. \& FRANÇA, G.R.F. 2018. Herpetofauna of Reserva Biológica Guaribas: a complex of Atlantic Forest and isolated Cerrado patches in Northeastern Brazil. Herpet. Notes 11:455-474.

MIJARES-URRUTIA, A. 1998. Los renacuajos de los anuros (Amphibia) altoandinos de Venezuela: morfología externa y claves. Rev. Biol. Trop. 46:119-143.

MOURA, G.J.B., ANDRADE, E.V.E., \& FREIRE, E.M.X. 2010. Amphibia, Anura, Microhylidae, Stereocyclops incrassatus Cope, 1870: distribution extension. CheckList 6:71-72.

NASCIMENTO, F.A.C. \& SKUK, G.O. 2006. O girino de Chiasmocleis alagoanus Cruz, Caramaschi \& Freire, 1999 (Anura: Microhylidae). Biota Neotrop. 6(3):1-5. http://www.biotaneotropica.org.br/v6n3/pt/abstract?shortcommunication+bn02506032006 (last access on 09/Apr/2020).

NASCIMENTO, F.A.C. \& SKUK, G.O. 2007. Description of the tadpole of Hylomantis granulosa (Anura: Hylidae). Zootaxa 1663(1):59-65.

NASCIMENTO, F.A.C., LIMA, M.G., SKUK, G.O. \& SÁ, R.O. de. 2009. The tadpole of Hypsiboas atlanticus (Anura, Hylidae) from northeastern Brazil. Iheringia, Série Zool. 99(4):431-436.

NASCIMENTO, F.A.C., LISBOA, B.S., SKUK, G.O. \& SÁ, R.O.D. 2010 Description of the tadpole of Proceratophrys renalis (Miranda-Ribeiro, 1920) (Anura: Cycloramphidae). S. Am. J. Herpetol. 5(3):241-248.

NIEWKOOP, P.D. \& FABER, J. 1994. Normal table of Xenopus laevis (Daudin): a systematical and chronological survey of the development from the fertilized egg till the end of metamorphosis. Garland Publishing, Inc., New York.

OLIVEIRA, F.F. \& LÍRIO-JÚNIOR, G.P. 2000. Anfibios anuros do Campus da Universidade Federal de Sergipe. Biol. Geral e Exp. 1(1):42-74.

OLIVEIRA, M.I.R.R., WEBER, L.N. \& RUGGERI, J. 2010. The tadpole of Physalaemus albifrons (Spix, 1824) (Anura, Leiuperidae). S. Am. J. Herpetol. 5(3):249-254.

PALMEIRA, C.N.S. \& GONÇALVES, U. 2015. Anurofauna de uma localidade na parte septentrional da Mata Atlântica, Alagoas, Brasil. Bol. Mus. Bio. Mello Leitão 37(1):141-163.

PEIXOTO, O.L. 1982. Observações sobre a larva de Pleurodema diplolistris (Peters, 1870) (Amphibia, Anura, Leptodactylidae). Rev. Bras. Biol. 42(3):631-633.

PEIXOTO, O.L. \& CRUZ, C.A.G. 1983. Girinos de espécies de Hyla do grupo "albomarginata" do sudeste brasileiro (Amphibia, Anura, Hylidae). Arq. da Univ. Fed. Rural Rio J. 6:155-163.

PEIXOTO, O.L. \& CRUZ, C.A.G. 1988. Descrição de duas espécies novas do gênero Phyllodytes Wagler (Amphibia, Anura, Hylidae). Rev. Bras. Biol. 48:265-272.

PEIXOTO, O.L., CARAMASCHI, U. \& FREIRE, E.M.X. 2003. Two new species of Phyllodytes (Anura: Hylidae) from the state of Alagoas, northeastern Brazil. Herpetologica 59(2):235-246

PEREIRA, E.N., LIRA, C.S., \& SANTOS, E.M. 2016. Ocupação, distribuição espacial e sazonal dos anfíbios anuros, em fragmento de Mata Atlântica. Revista Ibero-Americana de Ciências Ambientais 7(2):70-83.

PEZZUTI, T.L., LEITE, F.S.F. \& GARCIA, P.C.A. 2019. Chave de identificação interativa para os girinos do Quadrilátero Ferrífero, Minas Gerais, Sudeste do Brasil, version 1.0. http://biodiversus.com.br/saglab/aqf/chave/girinos/ (last access in 11/Apr/2020).
PIMENTA, B., COSTA, D., MURTA-FONSECA, R. \& PEZZUTI, T. 2014 Anfíbios - Alvorada de Minas - Conceição do Mato Dentro - Dom Joaquim. Bicho do Mato Editora, Belo Horizonte, Minas Gerais.

POMBAL JR., J.P. \& MADUREIRA, C.A. 1997. A new species of Physalaemus (Anura, Leptodactylidae) from the Atlantic rain forest of northeastern Brazil. Alytes 15(3):105-112.

POMBAL, J.P., MENEZES, V.A., FONTES, A.F., NUNES, I., ROCHA C.F.D. \& VAN-SLUYS, M. 2012. A second species of the casque-headed frog genus Corythomantis (Anura: Hylidae) from northeastern Brazil, the distribution of C. greeningi, and comments on the genus. Bol. Mus. Nac., Zool., (530): 1-14.

PRADO, G.M., ABRUNHOSA, P.A. \& WOGEL, H. 2003. Comportamento reprodutivo, vocalização e redescrição do girino de Phrynohyas mesopahea (Hensel, 1867) do sudeste do Brasil (Amphibia, Anura, Hylidae). Bol. do Mus. Nac., Zool., (510):1-11.

PROVETE, D.B., GAREY, M.V., SILVA, F.R. \& JORDANI, M.X. 2012. Knowledge gaps and bibliographical revision about descriptions of freeswimming anuran larvae from Brazil. North-Western J. Zool. 8(2):283-286.

PUGLIESE, A., ALVES, A.C.R. \& CARVALHO-E-SILVA, S.P. 2000. The tadpole of Hyla oliveirai and Hyla decipiens with notes on the Hyla microcephala group (Anura, Hylidae). Alytes 18(1-2):73-80.

RADA-DE-MARTÍNEZ, D. 1990. Contribución al conocimiento de las larvas de anfibios de Venezuela. Mem. Soc. Cienc. Nat. La Salle 49:391-403.

RIBEIRO, M.C., METZGER, J.P., MARTENSEN, A.C., PONZONI, F.J. \& HIROTA, M.M. 2009. The Brazilian Atlantic Forest: how much is left, and how is the remaining forest distributed? Implications for conservation. Biol. Conserv. 142(6):1141-1153.

ROBERTO, I.J. \& ÁVILA, R.W. 2013. The advertisement call of Phyllodytes gyrinaethes Peixoto, Caramaschi \& Freire, 2003 (Anura, Hylidae). Zootaxa 3669:193-196.

ROBERTO, I.J., OLIVEIRA, C.R., ARAÚJO-FILHO, J.A., OLIVEIRA, H.F. \& ÁVILA, R.W. 2017a. The herpetofauna of the Serra do Urubu mountain range: a key biodiversity area for conservation in the Brazilian Atlantic Forest. Pap. Avul. Zool. 57(27): 347-373.

ROBERTO, I.J., ARAUJO-VIEIRA, K., DE CARVALHO-E-SILVA, S.P. \& ÁVILA, R.W. 2017b. A new species of Sphaenorhynchus (Anura: Hylidae) from northeastern Brazil. Herpetologica 73(2):148-161.

RODRIGUES, G.V.D., NASCIMENTO, F.A.C., ALMEIDA, J.P.FA. \& MOTT, T. 2017. The tadpole of Scinax skuki (Anura: Hylidae) from the type locality, with a description of its larval skeleton. Stud. Neotrop. Fauna Environ. 52(3):204-215.

ROELANTS, K., HAAS, A. \& BOSSUYT, F. 2011. Anuran radiations and the evolution of tadpole morphospace. Proc. Natl. Acad. Sci. 108(21):87318736.

ROSSA-FERES, D.C., JIM, J. \& FONSECA, M.G. 2004. Diets of tadpoles from a temporary pond in southeastern Brazil (Amphibia, Anura). Ver. Bras. Zool. 21(4):745-754.

ROSSA-FERES, D.C. \& NOMURA, F. 2006. Characterization and taxonomic key for tadpoles (Amphibia: Anura) from the northwestern region of São Paulo State, Brazil. Biota Neotrop. 6(1):1-26. http://www.biotaneotropica. org.br/v6n1/pt/abstract?identification-key+bn00706012006 (last access on 09/Apr/2020)

ROSSA-FERES, D.C., VENESKY, M.D., NOMURA, F., ETEROVICK, P.C., VERA CANDIOTI, M.F., MENIN, M., JUNCÁ, F.A., SCHIESARI, L.C., HADDAD, C.F.B., GAREY, M.V., ANJOS, L.A. \& WASSERSUG, R.J. 2015. Taking tadpole biology into the 21st century: a consensus paper from the First Tadpoles International Workshop. Herpetol. Bras. 4(2):48-59.

ROSSA-FERES, D. C., GAREY, M.V., CARAMASCHI, U., NAPOLI, M.F., NOMURA, F., BISPO, A. A., BRASILEIRO, CR.A., THOMÉ, M.T.C., SAWAYA, R.J., CONTE, C.E., CRUZ, C.A.G., NASCIMENTO, L.B., GASPARINI, J.L., ALMEIDA, A.P. \& HADDAD, C.F.B. 2017. Anfíbios da Mata Atlântica: lista de espécies, histórico dos estudos, biologia e conservação. In Revisões em Zoologia: Mata Atlântica (E.L.A. MonteiroFilho \& C.E. Conte, orgs). Editora UFPR, Curitiba, p.237-314. 
RUAS, D.S., MENDES, C.V. M., SZPEITER, B.B. \& SOLÉ, M. 2012. The tadpole of Rhinella crucifer (Anura, Bufonidae) from southern Bahia, Brazil. Zootaxa 3299(1):66-68.

SANTANA, G.G., VIEIRA, W.L.S., PEREIRA-FILHO, A., DELFIM, F.R., LIMA, Y.C.C. \& VIEIRA, K. 2008. Herpetofauna em um fragmento de Floresta Atlântica no Estado da Paraíba, Região Nordeste do Brasil. Biotemas 21(1):75-84.

SANTANA, D.O., FRANCO, S.C., ROCHA, S.M., FREITAS, E.B., CARVALHO, C. B. \& FARIA, R.G. 2014. First record of Pipa carvalhoi (Miranda-Ribeiro, 1937) (Anura: Pipidae) in the state of Sergipe, northeastern Brazil. CheckList 10:407-408

SANTANA, G.G., TORQUATO, S., VIEIRA, K.S., VIEIRA, W.L.S., MONTENEGRO, P.F.G.P., AMORIM, F.O., SANTOSE, E.M., VASCONCELLOS, A. \& ALVES, R.R.N. 2015. Geographic distribution of Gastrotheca fissipes (Boulenger, 1888)(Anura: Hemiphractidae) in the Brazilian Atlantic Forest. Braz. J. Biol. 75(4):255-257.

SANTANA, G.G., AMORIM, F.O., SANTOS, E.M., VIEIRA, K.S., VIEIRA, W.L.S., MONTENEGRO, P.F.G.P. \& ALVES, R.R.N. 2016. Geographic distribution of Pristimantis vinhai (Bokermann, 1975)(Anura, Craugastoridae: Ceuthomantinae) in the Brazilian Atlantic Forest. Braz. J. Biol. 76(2):548-550.

SANTOS, E.M., SILVA, G.L., CAMPOS, T.F. \& QUIRINO, M.S. 2009. Geographic distribution: Ceratophrys joazeirensis. Herpet. Review 40:107.

SANTOS, E.M. \& SILVA, G.L. 2010. Geographic distribution: Phyllodytes acuminatus. Herpetol. Rev. 41:104.

SANTOS, D.L., ANDRADE, S.P., ROCHA, C.F., MACIEL, N.M., CARAMASCHI, U. \& VAZ-SILVA, W. 2017. Redescription of the tadpole of Odontophrynus carvalhoi Savage and Cei, 1965 (Anura, Odontophrynidae) with comments on the geographical distribution of the species. Zootaxa 4323(3):419-422.

SAVAGE, J.M., \& CEI. J.M. 1965. A review of the leptodactylid frog genus Odontophrynus. Herpetologica 21:178-195.

SCHULZE, A., JANSEN, M. \& KOÖHLER, G. 2015. Tadpole diversity of Bolivia's lowland anuran communities: molecular identification, morphological characterisation, and ecological assignment. Zootaxa 4016(1):1-111.

SHERRATT, E., VIDAL-GARCÍA, M., ANSTIS, M., \& KEOGH, J. S. 2017. Adult frogs and tadpoles have different macroevolutionary patterns across the Australian continent. Nat. Ecol. Evol. 1(9): 1385-1391.

SHERRATT, E., ANSTIS, M. \& KEOGH, J.S. 2018. Ecomorphological diversity of Australian tadpoles. Nat. Ecol. Evol. 8(24):12929-12939.
SOBRINHO, P.M.M., SANTOS, E.G., MELO, V.L., SANTOS, E.M. \& MOURA, G.J. 2017. First Record of Macrogenioglottus alipioi Carvalho, 1964 (Amphibia: Anura) for the state of Pernambuco, Brazil. Herpetol. Notes 9:103-104.

SOKOL, O.M. 1975. The phylogeny of anuran larvae: a new look. Copeia 1975(1):1-23.

STUDER, A., NUSBAUMER, L. \& SPICHIGER, R. 2015. Biodiversidade da Reserva Biológica de Pedra Talhada Alagoas, Pernambuco, Brasil. Boissiera (68):1-818.

TOLLEDO, J. \& TOLEDO, L.F. 2010. Tadpole of Rhinella jimi (Anura: Bufonidae) with comments on the tadpoles of species of the Rhinella marina group. J. Herpetol. 44(3):480-483.

VERDADE, V.K. \& RODRIGUES, M.T. 2007. Taxonomic review of Allobates (Anura, Aromobatidae) from the Atlantic Forest, Brazil. J. Herpetol. 41(4):566-580.

VIEIRA, W.L.D., SANTANA, G.G. \& VIEIRA, K.D.S. 2007a. Description of the tadpole of Leptodactylus vastus (Anura: Leptodactylidae). Zootaxa 1529(1):61-68.

VIEIRA, W. L. D. S., VIEIRA, K. D. S., \& SANTANA, G. G. 2007b. Description of the tadpoles of Proceratophrys cristiceps (Anura: Cycloramphidae, Odontophrynini). Zootaxa. 1397(1):17-24.

VIEIRA, W.L., SANTANA, G.G., SANTOS, S.C.N.C., ALVES, R.R.N. \& PEREIRA-FILHO, G.A. 2009. Description of the tadpoles of Phyllodytes brevirostris (Anura: Hylidae). Zootaxa 2119(1):66-68.

VILELA, B., NASCIMENTO, F.A.C. \& VITAL, M.V.C. 2018. Impacts of climate change on small-ranged amphibians of the Northern Atlantic forest. Oecologia Aust. 22(2):130-143.

VIZOTTO, L.D. 1967. Desenvolvimento de anuros da região norte-ocidental do Estado de São Paulo. Tese de Doutorado, Universidade de São Paulo, São Paulo.

WOGEL, H., ABRUNHOSA, P.A. \& POMBAL, J.P. 2000. Girinos de cinco espécies de anuros do Sudeste do Brasil (Amphibia: Hylidae, Leptodactylidae, Microhylidae). Bol. Mus. Nac., Zool., (427):1-16.

Received: $17 / 12 / 2018$

Revised: 17/04/2020

Accepted: 17/04/2020

Published online: 01/07/2020 


\section{Erratum}

Erratum: Morphological characterization and taxonomic key of tadpoles (Amphibia: Anura) from the northern region of the Atlantic Forest

In the article "Morphological characterization and taxonomic key of tadpoles (Amphibia: Anura) from the northern region of the Atlantic Forest", with the DOI code number: https://doi.org/10.1590/1676-0611-BN-2018-0718, published at Biota Neotropica 20(2): e20180718:

On page 10, where it was shown Sphaenorhynchus prasinus in Fig. 7D

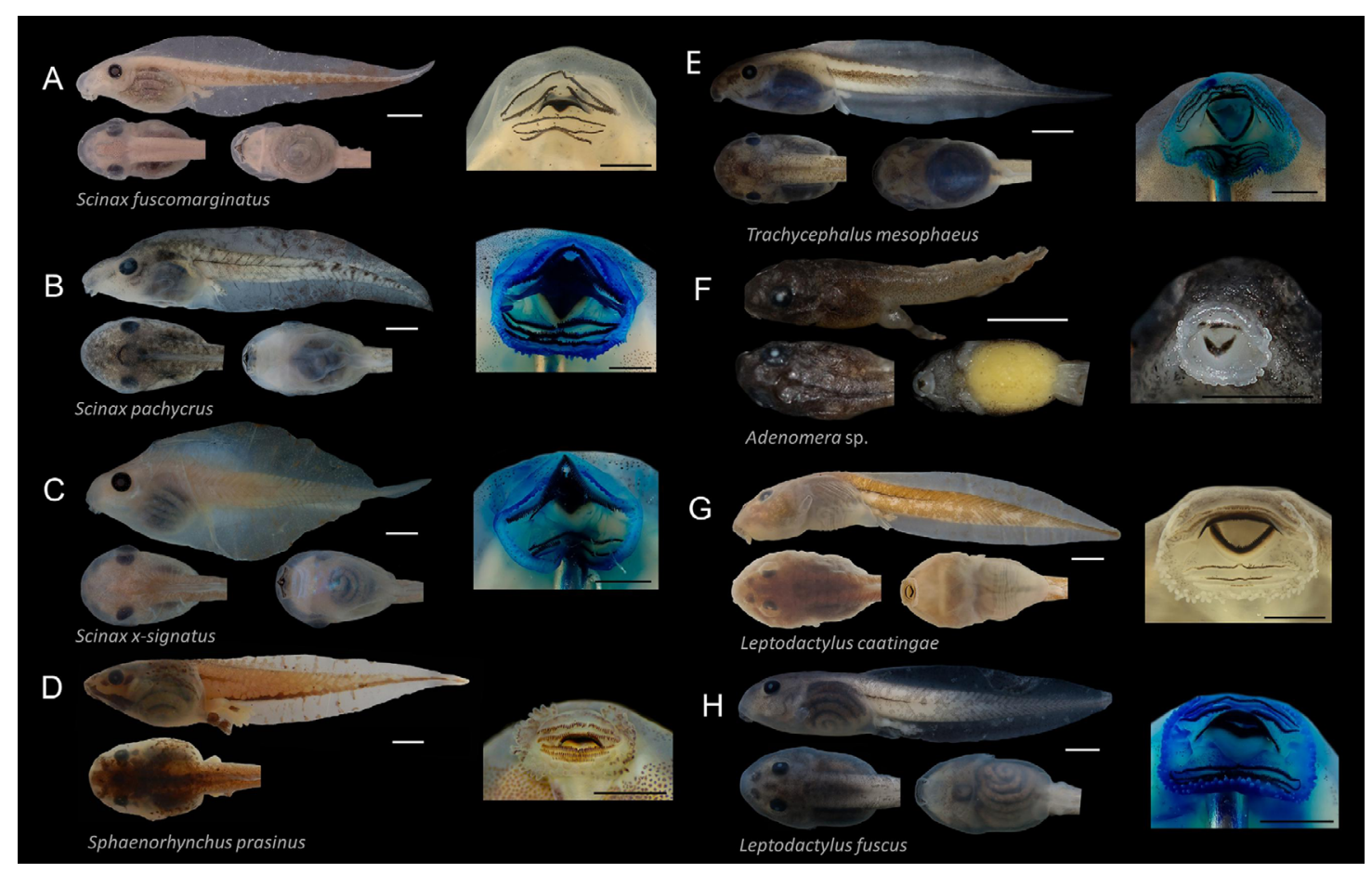

Should see:

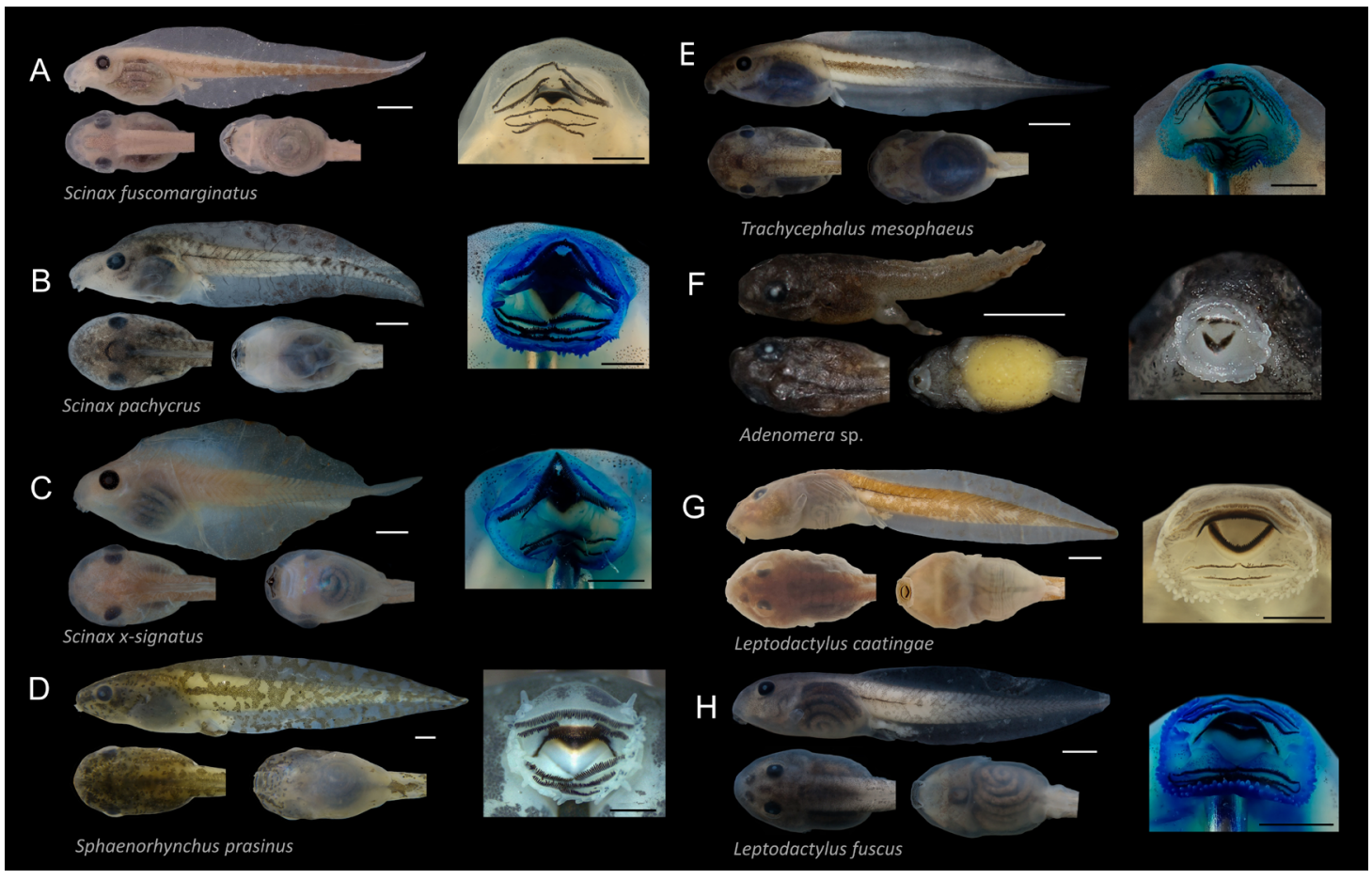


On page 11, where it was written:

Specimens examined. Sphaenorhynchus prasinus: MZUESC (these tadpoles were obtained in a recent sampling, right on with the closing of Universities during COVID-19 pandemic, preventing us from getting voucher numbers for these specimens, $\mathrm{n}=10$, stages $33-38$ ), municipality of Ilhéus, state of Bahia, Brazil.

Characteristics: Body ovoid in dorsal view, triangular-depressed in lateral view. Snout rounded in dorsal view, sloped in lateral view. Nostrils reniform, closer to tip of snout than to eyes. Eyes lateral. Oral disc anteroventral, not emarginate. Marginal papillae arranged ventrolaterally, with a wide dorsal gap, few large marginal papillae (highlighted papillae) on the anterolateral and posterolateral margins (large papillae about twice the size of the small papillae and alternating among them). LTRF 2(2)/3(1). Spiracle sinistral. Vent tube medial. Dorsal fin originating at tail-body junction, dorsal fin parallel to longitudinal axis of tail and ventral fin slightly arched. Tail length about $60 \%$ of total length, tail tip acute.

Should read:

Specimens examined. Sphaenorhynchus prasinus: MZUESC (these tadpoles were obtained in a recent sampling, right on with the closing of Universities during COVID-19 pandemic, preventing us from getting voucher numbers for these specimens, $\mathrm{n}=1$, stage 36), municipality of Ilhéus, state of Bahia, Brazil.

Characteristics: Body elliptical-elongated in dorsal view, triangular-depressed in lateral view. Snout rounded in dorsal view, sloped in lateral view. Nostrils reniform, anteriorly positioned, much closer to tip of snout than to eyes. Eyes lateral. Oral disc anterior, not emarginate. Marginal papillae arranged ventrolaterally, with a wide dorsal gap, few large marginal papillae (highlighted papillae) on the anterolateral and posterolateral margins (large papillae about twice the size of the small papillae and alternating among them). LTRF 2(2)/3(1). Spiracle sinistral. Vent tube medial. Dorsal fin originating at tail-body junction, dorsal fin slightly arched and ventral fin parallel to longitudinal axis of tail. Tail length about $60 \%$ of total length, tail tip acute.

On page 17, where it was written:

24a. (23b) Presence of long marginal papillae interspersed by conical shorter ones (Fig. 11w), body ovoid in dorsal view (Fig. 2c), vent tube medial (Fig. 11ah) Sphaenorhynchus prasinus (Fig. 7d)

24b. Marginal papillae with similar size and shape, body elliptical or elliptical-elongated in dorsal view (Figs. 2 a or $2 b$ ), vent tube dextral (Fig. 11ag) Scinax 25

Should read:

24a. (23b) Presence of long marginal papillae interspersed by conical shorter ones (Fig. 11w), vent tube medial (Fig. 11ah) ...Sphaenorhynchus prasinus (Fig. 7d) 24b. Marginal papillae with similar size and shape, vent tube dextral (Fig. 11ag) ... Scinax 25

In Supplementary Material 2, where it was written:

24a. (23b) Presença de papilas marginais longas intercaladas por papilas mais curtas e cônicas (Fig. 11w), corpo ovóide em vista dorsal (Fig. 2c), tubo cloacal mediano (Fig. 11ah)...

Sphaenorhynchus prasinus (Fig. 7d)

24b. Papilas marginais com tamanho e formato semelhantes, corpo elíptico ou elíptico-alongado em vista dorsal (Figs. 2 a ou $2 b$ ), tubo cloacal destral (Fig. 11ag).

Scinax 25

Should read:

24a. (23b) Presença de papilas marginais longas intercaladas por papilas mais curtas e cônicas (Fig. 11w), tubo cloacal mediano (Fig. 11ah)

24b. Papilas marginais com tamanho e formato semelhantes, tubo cloacal destral (Fig. 11ag) Sphaenorhynchus prasinus (Fig. 7d) Scinax 25 